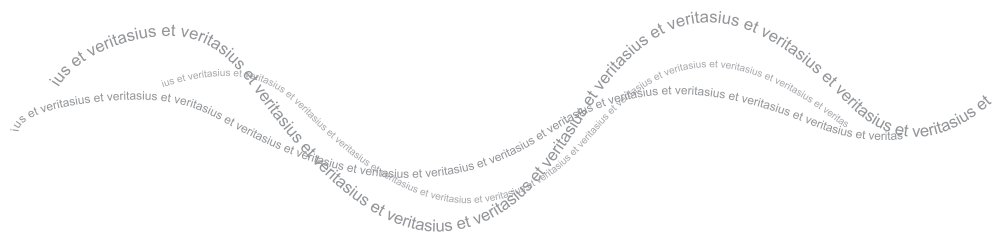

\title{
La Sociedad Anónima Abierta: algunas ideas para la reforma de su tratamiento legislativo(")
}

\section{The Open Stock Corporation: some ideas for the reform of its legislative treatment}

\section{A PESAR DE LOS IMPORTANTES ESFUERZOS REALIZADOS A FINES DE LOS AÑOS 90 CON LA DACIÓN DE LA LEY GENERAL DE SOCIEDADES Y DE LA LEY DEL MERCADO DE VALORES, LA LEGISLACIÓN PERUANA EN ESTA MATERIA ES HOY LAMENTABLEMENTE ASISTEMÁTICA, DESFASADA FRENTE A LOS CAMBIOS EN EL RÉGIMEN DE LA SOCIEDAD ANÓNIMA ABIERTA OCURRIDOS A NIVEL INTERNACIONAL, Y EN ALGUNOS CASOS CONTRADICTORIA E INCONVENIENTE.}

\begin{abstract}
Resumen: En el presente artículo, el autor se centra en el estudio de la institución jurídica de la Sociedad Anónima Abierta, analizando la forma como ha sido tratada en nuestra legislación a lo largo del tiempo. Asimismo, analiza su regulación actual en la Ley General de Sociedades, en la Ley del Mercado de Valores y en algunas disposiciones legales aisladas. Finalmente, brinda algunas ideas para la necesaria reforma de esta institución.
\end{abstract}

Palabras clave: Sociedad Anónima Abierta - Ley General de Sociedades - Ley de Mercado de Valores - Junta General de Accionistas - Directorio Finanzas Corporativas - Minorías

Abstract: In this paper, the author focuses on the study of the legal institution of the Open Stock Corporation, analyzing the way how it has been treated in our legislation over time. Furthermore, he analyzes its current regulation in the General Law of Corporations, the Securities Market Law and some isolated legal provisions. Finally, he provides some ideas for the necessary reform of this institution

(*) Abogado por la Pontificia Universidad Católica del Perú. Magíster en Derecho por la Universidad de Harvard. Experto en Derecho comercial general, fusiones y adquisiciones y transacciones financieras. Socio de Payet, Rey, Cauvi, Pérez Abogados. Correo electrónico: jap@prc.com.pe

$\left.{ }^{(* *}\right)$ El autor agradece los valiosos comentarios del doctor Joe Navarrete Pérez.

$\left.{ }^{* * *}\right)$ Nota del Editor: El artículo fue recibido el 23 de mayo del 2017 y su publicación fue aprobada el 26 de junio del mismo año. 
La Sociedad Anónima Abierta: algunas ideas para la reforma de su tratamiento legislativo The Open Stock Corporation: some ideas for the reform of its legislative treatment

Keywords: Open Stock Corporation - General Law of Corporations - Securities Market Law - General Meeting of Shareholders - Directory - Corporate Finance - Minorities

\section{Introducción}

La sociedad anónima abierta es el paradigma de la sociedad anónima. El modelo de sociedad con personalidad jurídica independiente de sus socios, con capital propio representado por títulos negociables, con responsabilidad limitada y con una administración propia distinta de sus accionistas, responde a la necesidad de obtener capitales de terceros que permitan el desarrollo de grandes negocios. Esta modalidad de organización jurídica empresarial surge en el contexto de las grandes empresas comerciales coloniales, que requerían acopiar inmensos capitales de muchos inversionistas distintos, para poder hacer frente a las grandes necesidades financieras de los emprendimientos comerciales de la época. Como lo explica Galgano, hablando de las compañías de las indias de los siglos XVII y XVIII: "Estas son las primeras grandes empresas de la era moderna, los arquetipos de la forma jurídica general de la empresa capitalista que establecen las codificaciones del siglo XIX: la sociedad por acciones o anónima" (Galgano 1981, 75).

$Y$ es que si bien estas sociedades no nacen con todas las características de la gran sociedad anónima de accionariado difundido contemporánea y tienen características particulares que las hacen únicas (como el nacer de un acto soberano y gozar de un monopolio comercial que las convierte casi en soberanas en sí mismas), sí son las pioneras de la gran sociedad bursátil por acciones de hoy. Las dos principales sociedades coloniales europeas de esta época, la Compañía Holandesa de las Indias Orientales (Verenigde Oostindische Compagnie, VOC), fundada en 1602, y la Compañía Inglesa de las Indias Orientales (East India Company), fundada el 31 de diciembre de 1600, fueron ambas sociedades con un gran volumen de negocios, con un capital considerable dividido en acciones, libremente negociables en el ámbito de las incipientes Bolsas de Valores de Amsterdam y de Londres, y con una gestión independiente y autónoma. La vinculación de ambas sociedades coloniales con el mercado de valores es consustancial desde el primer momento. De acuerdo con Harris, las acciones de la East India Company se negociaban inicialmente a través de reuniones de potenciales compradores y vendedores, frecuentemente en las mismas oficinas de la sociedad, pero luego pasaron a negociarse en la London Stock Exchange y las acciones de la VOC se negociaron en el mercado de Amsterdam desde la fundación de la compañía(1).

Pero si bien la sociedad de accionariado difundido puede ser el paradigma de la sociedad anónima, no es menos cierto que esta institución jurídica tiene una utilidad y una función también para emprendimientos de capital cerrado, con socios unidos por vínculos personales o de negocios (y no anónimos) y consiguientemente con restricciones 0 limitaciones importantes a la transferencia de las acciones. Esta segunda dimensión de la sociedad anónima no es menos importante que la anterior.

A pesar de que ambos tipos de sociedades anónimas, la gran sociedad de accionariado difundido y la sociedad de capital cerrado, tienen muchos elementos comunes, no puede perderse de vista que la dispersión accionarial genera una problemática especial que es más bien típica de las sociedades anónimas de tipo abierto. En efecto, es en una sociedad de accionariado disperso en donde se presentan con especial intensidad los problemas de asimetría informativa, de agencia y conflictos de interés, y de acción colectiva, que muchas veces se atribuyen a todas las sociedades anónimas. $Y$ esta diferencia se da tanto en la sociedad de accionariado difundido de corte anglosajón, con accionistas dispersos y ausencia de accionista controlador, como en las sociedades anónimas bursátiles de corte europeo continental, con núcleos accionariales de control y accionistas

(1) Véase Ron Harris, Finance and the first corporations, 10 y siguientes. Disponible en: http://ssrn.com/abstract=1330459. 
José Antonio Payet Puccio

minoritarios dispersos(2). Como lo ha expresado el Informe del Grupo de Reflexión de la Unión Europea sobre el Futuro del Derecho de Sociedades publicado en 2011, "una compañía con grupo numeroso y disperso de accionistas puede en ciertos aspectos ameritar una regulación diferente que una compañía con un circulo estrecho de accionistas poco numerosos" $(2011,8)$. Es por esta razón que numerosas legislaciones tratan en forma diferente a las sociedades anónimas de corte cerrado de aquellas de carácter abierto o cuyas acciones se negocian en una Bolsa de Valores.

En este artículo revisaré la forma como ha sido tratada la sociedad anónima abierta en nuestra legislación a lo largo del tiempo, examinaré la regulación actual de esta forma de sociedad en la Ley General de Sociedades, en la Ley del Mercado de Valores y en algunas disposiciones legales aisladas, y esbozaré algunas ideas para la necesaria reforma de esta institución. A pesar de los importantes esfuerzos realizados a fines de los años 90 con la dación de la Ley General de Sociedades y de la Ley del Mercado de Valores, la legislación peruana en esta materia es hoy lamentablemente asistemática, desfasada frente a los cambios en el régimen de la sociedad anónima abierta ocurridos a nivel internacional, y en algunos casos contradictoria e inconveniente. Creo que, por ello, es indispensable emprender una profunda reforma del régimen legal de esta importante institución, atendiendo a los cambios ocurridos a nivel internacional, y a la realidad y las perspectivas de nuestro mercado.

Como cuestión metodológica, me referiré en este artículo como sociedad anónima abierta a la sociedad anónima que tiene vocación de tal, básicamente por su conexión con el mercado público de valores, y no necesariamente a la sociedad que cumple con la definición legal actualmente vigente para ser considerada como una sociedad anónima abierta.

\section{Evolución normativa de la sociedad anónima abierta en el Perú}

La sociedad anónima fue incorporada a nuestro Derecho republicano primero en el Código de Comercio de 1853 y luego en el Código de Comercio de 1902, los cuales, como se sabe, fueron prácticamente calco y copia de los Códigos de Comercio españoles de 1829 y de 1885, respectivamente. Estos códigos no incluyeron un tratamiento especial para las sociedades anónimas abiertas.

La Ley de Sociedades Mercantiles de 1966 (3) no trató en forma separada a la sociedad anónima cerrada de la abierta. Sin embargo, sí dispuso que las sociedades que tuvieran más de cincuenta accionistas o un capital no menor de veinte millones de soles o hicieran oferta pública de acciones, debían contar con un órgano especial, denominado Consejo de Vigilancia, elegido por la Junta General y conformado por personas que no fueran directores ni gerentes de la sociedad. Este órgano, entre otras cosas, tenía facultades para supervisar el cumplimiento del estatuto y de los acuerdos societarios por el Directorio, cuidar de la regularidad de los libros y registros de la sociedad y disponer la realización de auditorías contables. Así, pues, esta ley preveía un tratamiento especial para las sociedades con un determinado capital mínimo o con un determinado número mínimo de accionistas. El Consejo de Vigilancia tuvo muy poco uso(4) y fue eliminado en la

(2) Véase generalmente José Antonio Payet, "Empresa, Gobierno Corporativo y Derecho de Sociedades: reflexiones sobre la protección de las minorías," Themis 46 (2003): 77-103.

(3) Ley 16123, luego reestructurada por Decreto Legislativo 311 para incorporar el tratamiento de las sociedades civiles, pasando a denominarse Ley General de Sociedades.

(4) La Ley General de Sociedades establecía que la sociedad no requería tener Consejo de Vigilancia si su Directorio era elegido por unanimidad o de acuerdo con el sistema de votación acumulativa previsto en el artículo 158 de la misma norma, o si tenía auditoria externa permanente a cargo de contadores públicos colegiados. Dada la amplitud de la excepción, en la práctica el Consejo de Vigilancia no tuvo aplicación relevante. 
La Sociedad Anónima Abierta: algunas ideas para la reforma de su tratamiento legislativo The Open Stock Corporation: some ideas for the reform of its legislative treatment

Ley General de Sociedades de 1998. Sin perjuicio de ello, la existencia de este órgano dentro de la configuración de la sociedad anónima es el antecedente más remoto de un tratamiento especial a la sociedad anónima que podríamos denominar abierta en el derecho nacional.

\subsection{EI Decreto Supremo 089-87-EF}

La primera referencia expresa a las sociedades anónimas abiertas en el ordenamiento societario peruano se da por el Decreto Supremo 089-87-EF, que reglamenta la oferta pública de valores mobiliarios ${ }^{(5)}$. Este decreto establece una reglamentación orgánica de la oferta publica primaria de valores mobiliarios en el Perú, incluyendo la definición de valor mobiliario y de oferta pública, la obligación de inscribir los valores objeto de oferta pública en un registro especial en la Superintendencia del Mercado de Valores (entonces denominada Comisión Nacional Supervisora de Empresas y Valores - CONASEV), y el requisito de elaborar y poner a disposición de los destinatarios de una oferta pública primaria un prospecto informativo y de contar con auditoría externa permanente, que constituye uno de los antecedentes de la actual Ley del Mercado de Valores.

El Título IV del Decreto Supremo 089-87-EF contiene un conjunto de disposiciones especiales aplicables a ciertas sociedades, que se denominó sociedades anónimas abiertas, las que fueron definidas como las que tengan sus acciones ordinarias inscritas en Bolsa y además que el treinta por ciento (30\%) como mínimo de su capital social se encuentre difundido entre el público, señalándose para estos efectos se entiende como el público a un número mínimo de 50 accionistas que individualmente no posea más del tres por ciento (3\%) del capital social. Así, de acuerdo con el Decreto Supremo 089-87-EF, el carácter de sociedad anónima abierta se adquiría por la conjunción de dos características. La primera era que la sociedad tenga sus acciones ordinarias inscritas en Bolsa. La segunda estaba vinculada al grado de dispersión del accionariado. Las sociedades anónimas abiertas debían tener como mínimo el $30 \%$ de su capital social en poder de al menos 50 accionistas cuya participación individual no fuere mayor al $3 \%{ }^{(6)}$.
El Decreto Supremo 089-87-EF estableció la posibilidad de que las sociedades anónimas abiertas emitieran acciones con preferencia sin derecho a voto, disponiendo, no obstante (en armonía con el dirigismo económico entonces en boga), que tales títulos gozarán de una rentabilidad anual garantizada no inferior al cincuenta por ciento (50\%) de la tasa de interés vigente para las operaciones activas a largo plazo del sistema financiero, siempre y cuando la sociedad obtenga utilidades en el ejercicio correspondiente. Asimismo, facultó a dichas sociedades a emitir obligaciones convertibles en acciones. La Ley General de Sociedades vigente en ese momento no contemplaba ni las acciones sin derecho a voto ni las obligaciones convertibles.

De otro lado, el Decreto Supremo 089-87-EF contenía también un conjunto de disposiciones de reforzamiento del gobierno corporativo y la protección de los accionistas minoritarios en las sociedades anónimas abiertas. Estas disposiciones incluyeron las siguientes:

a) La obligación de la sociedad de proporcionar información fuera de junta en caso lo solicitasen accionistas que representasen al menos el 3\% del capital social pagado, salvo que se tratase de asuntos confidenciales, facultando a CONASEV a determinar el carácter confidencial de una información en caso de discrepancia.

b) La facultad de CONASEV de convocar a la Junta General de Accionistas de la sociedad a solicitud de accionistas en los casos del artículo 125 (accionistas que representan al menos el $20 \%$ del capital)

(5) Véase Fernando Vidal Ramírez, La Bolsa de Valores (Lima: Cultural Cuzco, 1988), 218 y siguientes.

(6) Este límite no fue planteado como un límite estático, pues el carácter de sociedad anónima abierta debía revisarse luego de dos años, y la sociedad solo mantendría el carácter de abierta "si el número de acciones distribuidas ha aumentado en tres por ciento ( $3 \%$ ) hasta alcanzar un máximo de cuarenta y nueve por ciento (49\%) y el número de accionistas permanece igual o superior a 50 ". 


\section{José Antonio Payet Puccio}

y 126 (convocatoria de junta obligatoria anual a solicitud de cualquier accionista) de la Ley General de Sociedades entonces vigente.

c) La obligación de la sociedad de contar con Consejo de Vigilancia, aunque el Directorio fuese elegido con participación de la minoría y se contase con auditoria externa.

d) Otorgamiento del derecho de separación a los accionistas en caso que la sociedad deje de estar inscrita en el Registro Público de Valores Mobiliarios.

Asimismo, además de las disposiciones aplicables específicamente a las sociedades anónimas abiertas, el Decreto Supremo 089-87-EF estableció, para todas las sociedades inscritas en Bolsa, aunque no fueran sociedades anónimas abiertas, otras importantes disposiciones especiales en materia de gobierno corporativo:

a) La obligación de aplicar el sistema de voto acumulativo para la elección del Directorio, con voto secreto, incluso si la elección fuera unánime. La norma señaló que "el voto será secreto y los resultados de la votación serán consignados en el acta respectiva, incluyendo los nombres y los votos de quienes no fueron proclamados directores".

b) La obligación de contar con auditoría externa permanente a cargo de auditores independientes designados por la Junta General de Accionistas ${ }^{(7)}$.

c) El carácter libremente transferible de los valores mobiliarios "siendo nula toda limitación estatutaria a su libre circulación, salvo los casos previstos por normas legales expresas".

d) El carácter libremente negociable del derecho de suscripción preferente.
Debido a lo exigente de la definición de sociedad anónima abierta contenida en el Decreto Supremo 089-87-EF, en cuanto a que exigía un porcentaje de al menos $30 \%$ del capital en manos de accionistas minoritarios, las disposiciones de este referidas a estas sociedades tuvieron una muy limitada aplicación práctica. Asimismo, algunas disposiciones del Decreto eran claramente inoperantes, como las referidas a las acciones preferentes sin derecho a voto.

Sin perjuicio de ello, el Decreto incluyó algunas innovaciones importantes a nivel normativo, como la categorización de la sociedad anónima abierta como un tipo especial de sociedad anónima objeto de una regulación especial, las normas referidas a la elección del Directorio con voto secreto, el derecho de minoría calificada de exigir información societaria, la libre negociación del derecho de suscripción preferente(8), así como la atribución de ciertas facultades de supervisión a la CONASEV sobre las sociedades abiertas. Por ello, consideramos que, más allá de su limitada aplicación práctica y sus defectos puntuales, este Decreto Supremo constituye un importante antecedente teórico en el tratamiento de las sociedades anónimas abiertas en el Perú.

\subsection{El Decreto Legislativo 672 y las Sociedades de Accionariado Difundido}

En el contexto del proceso de liberalización de la economía y reforma que se inicia en el Perú a principios de la década de 1990, y como parte del paquete liberalizador de decretos legislativos que se expiden en 1991 en el

(7) La obligación de los emisores de valores de oferta pública de contar con estados financieros auditados existía en la legislación anterior al Decreto Supremo 089-87-EF. Véase Fernando Vidal Ramírez, La Bolsa en el Perú (Lima: Cultural Cuzco, 1988), 419 y siguientes.

(8) Aparejada con la obligación de emitir un certificado que contenga ese derecho, el Certificado de Suscripción Preferente, dispuesta por el Decreto Supremo 083-87-EF. 
La Sociedad Anónima Abierta: algunas ideas para la reforma de su tratamiento legislativo The Open Stock Corporation: some ideas for the reform of its legislative treatment

marco de las facultades delegadas para legislar conferidas por el Congreso de la República al Poder Ejecutivo, se dictaron en 1991 el Decreto Legislativo 672 que reguló las llamadas sociedades con accionariado difundido y el Decreto Legislativo 755, Ley del Mercado de Valores, que reguló las sociedades anónimas abiertas. Ambas disposiciones constituyen antecedentes importantes para el tema que nos ocupa.

El Decreto Legislativo 672 se dicta con el propósito declarado en su parte considerativa de "introducir normas complementarias [a las de la Ley General de Sociedades] que establezcan reglas propias para las empresas que, organizadas como sociedades anónimas, encuentren atractivo y manejable el mecanismo del accionariado difundido como sistema para captar recursos, fomentar la pequeña inversión privada, y difundir la propiedad empresarial". El legislador percibió la necesidad de dictar dichas normas considerando que "la actual Ley General de Sociedades no establece un marco adecuado para la promoción del accionariado difundido, pues dicta normas y requisitos propios de empresas con alta concentración de titularidad sobre el capital, convirtiendo en poco atractivas e inviables las estructuras societarias basadas total o parcialmente en accionariado difundido". Se trata, en mi opinión, de una visión bastante distorsionada de la legislación societaria entonces vigente, que no obstante algunos defectos, sí contemplaba ya reglas bastante apropiadas en materia de sociedades con accionariado difundido. De hecho, como se verá seguidamente, salvo por algunos aspectos puntuales, el Decreto Legislativo 672 no significó una innovación legislativa importante ${ }^{(9)}$.

El Decreto Legislativo crea una nueva categoría de sociedades, a las que denomina sociedades de accionariado difundido, definiéndolas como aquellas en las que no menos de mil accionistas sean titulares de no menos del $25 \%$ del capital social suscrito, añadiendo que para estos efectos no se computarán a los accionistas que sean titulares de acciones que representaran más del uno por ciento del total emitido. Nótese la importante elevación del filtro cuantitativo de dispersión accionarial que se da en la definición, frente a la establecida en el Decreto Supremo 089-87-EF para la sociedad anónima abierta. Teniendo en cuenta el gran nivel de concentración que existía en las sociedades anónimas peruanas al momento de dictarse la norma, parece forzoso concluir que el Gobierno estaba legislando no tanto para la situación actual, sino para una situación por venir. En este contexto, no puede dejar de mencionarse el proceso de cambio del modelo empresarial de las cooperativas azucareras agrarias creadas en el marco de la Reforma Agraria de los años 70, entidades con miles de socios trabajadores cuya conversión a sociedades anónimas se había habilitado recientemente ${ }^{(10)}$. Asimismo, el proceso de privatización de las empresas de la actividad empresarial del Estado que recién se iniciaba y en el cual la promoción del accionariado difundido era parte importante.

El Decreto Legislativo 672 estableció la obligación de que las sociedades de accionariado difundido inscribiesen sus acciones en una Bolsa de Valores para su negociación en Rueda de Bolsa. En este sentido, significó un cambio importante, pues hasta entonces el hecho de que una sociedad tuviese un grado importante de dispersión de su accionariado no la obligaba a listar. De hecho, bajo el Decreto Supremo 089-87-EF, el listado en Bolsa era un requisito para ser considerada una sociedad como sociedad anónima abierta, no una obligación resultante de la categorización legal. De la mano con esta obligación, el Decreto

(9) Véase una acertada crítica a esta norma en José Tola, El Mercado de Valores y la Bolsa en el Perú (Lima: Mass Comunicación, 1994), 215 y siguientes.

(10) El proceso de cambio de modelo empresarial (en rigor, conversión a sociedades anónimas) de las cooperativas azucareras se inició con la dación del Decreto Legislativo 653 y del Decreto Supremo 018-91-AG, en el año 1991. Estas sociedades fueron luego objeto de una profusa legislación especial que incluye, entre otras disposiciones, el Decreto Legislativo 802, Ley de Saneamiento Económico - Financiero de las Empresas Agrarias Azucareras, y la Ley 28027, Ley de Actividad Empresarial de la Industria Azucarera. 


\section{José Antonio Payet Puccio}

Legislativo 672 estableció que el estatuto de estas sociedades no podría contener disposición alguna que restringiese la libre negociación y transferencia de las acciones y dispuso que "no se reconoce y es inválida la concesión de derechos preferenciales a los accionistas para adquirir acciones en caso de transferencia de estas".

Con la finalidad de facilitar la oferta pública primaria, el Decreto Legislativo 672 también permitió la emisión de acciones sin derecho de suscripción preferente, aunque sujetando esta facultad de la Junta General "a su aprobación por CONASEV, debiendo acreditar la Sociedad, para este efecto, de forma razonable, que la emisión no se destinara directa ni indirectamente a mejorar la posición accionaria de alguno de los socios de la Sociedad".

La norma permitió a las sociedades de accionariado difundido adquirir y mantener en cartera para su negociación en Bolsa acciones de propia emisión, pero con un máximo de $1 \%$ del capital social suscrito y por un plazo máximo de cuatro meses. Esta forma de autocartera no estaba autorizada por la Ley General de Sociedades entonces vigente. Asimismo, amplió la potestad de la junta de delegar al Directorio la facultad de aumentar el capital hasta por un monto igual al capital existente. La Ley General de Sociedades solo facultaba la delegación hasta por la mitad del capital.

Por otro lado, el Decreto Legislativo 672 extendió el plazo para la convocatoria a Junta General de Accionistas a veinticinco días y redujo el quórum calificado para los casos previstos en el artículo 134 de la Ley General de Sociedades entonces vigente, a $51 \%$ del capital pagado en primera convocatoria, $25 \%$ para la segunda y el número de acciones que concurra para la tercera, estableciendo que en todos los casos los acuerdos se podrían adoptar con la mayoría absoluta de las acciones representadas en la junta. Asimismo, estableció que "el Estatuto no puede exigir quórum ni mayoría más alta". Estos son antecedentes que fueron recogidos en la Ley General de Sociedades vigente actualmente al abordarse la regulación de la sociedad anónima abierta.

El Decreto Legislativo 672 también contempló una serie de disposiciones para asegurar que los accionistas dispersos pudieran efectivamente participar en las juntas generales y ejercer sus derechos. Así, estableció la obligación del Directorio de informar a los accionistas el número de acciones que les pertenecían, el porcentaje que representaban y los derechos que otorgaban, ordenó que una sociedad auditora debía certificar la realidad de la matrícula de acciones de forma tal que se garantice que esta exprese la verdadera estructura accionaria de la empresa, y normó con gran detalle un proceso especial para que los accionistas de estas sociedades puedan elegir representantes para que concurran y voten en nombre de ellos en las juntas generales de accionistas. Estas disposiciones seguramente se redactaron pensando en la situación de las cooperativas en proceso de transformación a sociedades anónimas, en las que la cuestión del importe del capital social, el número de acciones y su distribución entre los antiguos socios trabajadores no era pacífica.

Finalmente, el Decreto Legislativo 672 confirió mayores facultades a la CONASEV respecto de las sociedades de accionariado difundido de las que gozaba bajo el Decreto Supremo 089-87-EF sobre las sociedades abiertas. Así, señaló que "CONASEV está encargada de supervisar, en forma permanente, las actividades de las Sociedades de Accionariado Difundido" confiriéndole las atribuciones de cuidar que estas presenten estados financieros anuales auditados y estados financieros semestrales refrendados por contador y que entreguen a los accionistas "la información esencial sobre la empresas y sus negocios", así como la facultad de convocar a Junta General de Accionistas cuando lo soliciten accionistas que representen el $5 \%$ del capital (porcentaje que luego fue elevado al $15 \%$ ) o cuando la sociedad no cumpla con convocar a Junta General de Accionistas o elección de representantes a la Junta General, de supervisar las elecciones del Directorio y de representantes y de conocer y resolver en la vía administrativa cualquier asunto relacionado con dichas elecciones.

No obstante que el Decreto Legislativo 672 limitó su ámbito de aplicación a un universo 
La Sociedad Anónima Abierta: algunas ideas para la reforma de su tratamiento legislativo The Open Stock Corporation: some ideas for the reform of its legislative treatment

bastante pequeño de sociedades, y que como se verá seguidamente su vigencia en el tiempo fue bastante limitada, sí trajo algunas innovaciones importantes, que fueron luego recogidas en el tratamiento de la sociedad anónima abierta en la Ley General de Sociedades vigente, como la posibilidad de excluir el derecho de suscripción preferente (aunque sujeto a un requisito sin mucho sentido, como es la aprobación administrativa), y la anticipación de 25 días para la convocatoria y la exigencia de quórums y mayorías menores para la Junta General de Accionistas.

\subsection{El Decreto Legislativo 755 , Ley del Mercado de Valores} Menos de dos meses después de la promulgación del Decreto Legislativo 672, sobre sociedades de accionariado difundido, se promulgó el Decreto Legislativo 755, Ley del Mercado de Valores. Esta norma, la primera en el Perú que reguló en un cuerpo orgánico y de manera sistemática el mercado de valores como un todo incluyendo la transparencia del mercado, los mercados primarios y secundarios, las Bolsas de Valores y los intermediarios del mercado, incorporó también, en el Titulo IX, referido a la protección del inversionista, un capítulo especial dedicado a las sociedades anónimas abiertas.

El Decreto Legislativo 755 definió como sociedades anónimas abiertas a "aquellas que realizan oferta pública de sus acciones o cuyo capital social se encuentre en poder de más de 25 accionistas que posean en conjunto más del treinta por ciento $(30 \%)$ sin que individualmente ninguno posea más del $5 \%$ ". De esa manera, se redujo de cincuenta a veinticinco el número mínimo de accionistas minoritarios previsto en el Decreto Supremo 089-87-EF y se incrementó de 3\% a $5 \%$ el porcentaje máximo que podía poseer cada uno de ellos para que la sociedad sea considerada como abierta, manteniéndose el porcentaje global de capital flotante de $30 \%$. Asimismo, se extendió la definición a las sociedades que hicieran oferta pública (presumiblemente primaria) de sus acciones, como una categoría separada.

La norma recogió algunas de las disposiciones que ya contenía el Decreto Supremo 089-87-EF, como la que les permitía a las sociedades anónimas abiertas emitir obligaciones convertibles en acciones, la que obligaba al Directorio a constituirse necesariamente con el sistema de votación acumulativa previsto en la Ley General de Sociedades (pero omitiendo el requisito de que el voto para elegir directores sea secreto), la que facultaba a la CONASEV a convocar a la Junta General en los supuestos de los artículos 125 y 126 de la Ley General de Sociedades, la que consagraba el derecho de separación en los casos en los que la sociedad dejase de estar inscrita en el Registro Público de Valores e Intermediarios y la que obligaba a la sociedad a proporcionar información fuera de junta cuando ella fuera solicitada por accionistas que representasen al menos el 3\% del capital pagado. El Decreto Legislativo 755 también incluyó en un capítulo especial la regulación del certificado de suscripción preferente, el mismo que se estableció como obligatorio para las sociedades que tuviesen sus acciones de capital social inscritas en Bolsa, fueran abiertas o no.

Sin perjuicio de lo anterior, que implicaba más que todo un reordenamiento y un perfeccionamiento de la normativa existente, el Decreto Legislativo 755 trajo algunas novedades importantes para las sociedades anónimas abiertas, no todas ellas acertadas. Así, facultó a las sociedades anónimas abiertas a emitir acciones por debajo de la par, lo cual es un acierto. Sin embargo, estableció también que las sociedades que hicieran oferta pública de valores quedaban "obligadas a repartir el porcentaje que fije la CONASEV de las utilidades netas obtenidas en cada ejercicio económico, previa deducción de las utilidades netas obtenidas en cada ejercicio", lo cual es un grave error. Igualmente, el Decreto Legislativo 755 prohibió a estas sociedades otorgar a sus directores una participación en las utilidades superior al $10 \%$.

La norma también otorgó a accionistas que representen más del $25 \%$ del capital social de cualquier sociedad anónima, el derecho a solicitar la inscripción de Bolsa de sus acciones, las cuales para tal efecto debían quedar comprendidas en una nueva clase o serie. Esta fue una innovación importante, permitiendo a accionistas con una participación significativa forzar a la sociedad 


\section{José Antonio Payet Puccio}

a listar sus acciones -con lo cual esta queda a las obligaciones de revelación de la Ley del Mercado de Valores, entre otrasaun contra la voluntad de la sociedad o de la mayoría de sus accionistas. Anteriormente, la CONASEV había establecido por vía reglamentaria el derecho de los accionistas que representaban el $25 \%$ o más de las acciones de exigir la inscripción en Bolsa, pero esta disposición reglamentaria había sido declarada ilegal e inaplicada por la Corte Suprema de la República ${ }^{(11)}$.

Finalmente, la norma dispuso que las sociedades anónimas abiertas quedaban sujetas al control y supervisión de la CONASEV.

El Decreto Legislativo 755 también estableció, dentro de la sección referida a la oferta pública primaria, un conjunto de disposiciones relacionadas con el gobierno corporativo de los emisores, fueran o no sociedades abiertas. Entre ellas se encontraban las prohibiciones para los directores y gerentes de "recibir en préstamo dinero o bienes de la sociedad, o usar en provecho propio, o de quienes tengan con ellos relación indirecta, los bienes, servicios o créditos de la sociedad, sin contar con la autorización del Directorio", "emplear en su propio beneficio, o en el de quienes tengan con ellos relación indirecta, con detrimento del interés social, las oportunidades comerciales de que tuvieran conocimiento en razón de su cargo" o "valerse del cargo para, por cualquier medio y con perjuicio del interés social, obtener ventajas indebidas o para sí o para las personas con las que tenga relación indirecta". Asimismo, estableció que "para la celebración por un emisor de actos o contratos en los que tenga interés alguno de sus directores, gerentes o personas que tengan con ellos relación indirecta, se requiere la aprobación del Directorio (...)".

Este era el panorama legislativo de la sociedad anónima abierta en el Perú hasta la entrada en vigencia de la actual Ley del Mercado de Valores (Decreto Legislativo 861) y de la actual Ley General de Sociedades (Ley 26887). Sobre la normativa base de la Ley General de Sociedades (Decreto Legislativo 311) se superponían dos conjuntos normativos especiales. Uno, establecido por la Ley del Mercado de Valores (Decreto Legislativo 755), contemplaba normas especiales para las sociedades definidas como abiertas. El otro conjunto normativo especial, establecido por el Decreto Legislativo 672, era aplicable específicamente a las denominadas sociedades de accionariado difundido, incluyendo a aquellas sociedades anónimas abiertas que también cumplían con el requisito de difusión de accionariado previsto en la norma. Adicionalmente, el Decreto Legislativo 755 contenía un conjunto de normas de reforzamiento de la transparencia del gobierno corporativo de las sociedades que hacían oferta pública primaria de valores, fueran o no de carácter accionario, y fueran dichas sociedades abiertas o no.

\section{Regulación actual de la sociedad anónima abierta}

El 21 de octubre de 1996 se expidió, por Decreto Legislativo 861, la nueva Ley del Mercado de Valores (En adelante, "LMV"), que sustituyó a la que había sido aprobada por Decreto Legislativo 755. Poco más de un año después, el 5 de diciembre de 1997, se promulgó una nueva Ley General de Sociedades (En adelante, "LGS"), que entró en vigencia el 1 de enero de 1998. Ambas disposiciones, con algunas modificaciones puntuales y unas pocas normas adicionales aisladas que se han dado a lo largo del tiempo, han estado vigentes por aproximadamente veinte años y constituyen hoy el marco normativo de las sociedades anónimas abiertas en el Perú.

Con la expedición de la LMV y la LGS quedó modificado en forma sustantiva el marco legal de las sociedades anónimas abiertas. Este marco normativo, además, pasó a estar contenido fundamentalmente en la legislación societaria, antes que en leyes especiales o en la legislación del mercado de valores, aunque lamentablemente dicho reordenamiento no fue completo.

(11) Véase Fernando Vidal Ramírez, La Bolsa en el Perú (Lima: Cultural Cuzco, 1988), 276 y siguientes. 
La Sociedad Anónima Abierta: algunas ideas para la reforma de su tratamiento legislativo
The Open Stock Corporation: some ideas for the reform of its legislative treatment

En primer lugar, la LGS derogó el Decreto Legislativo 672, con lo que la categoría especial de las denominadas sociedades de accionariado difundido quedó eliminada. Asimismo, la LGS derogó las disposiciones del Decreto Legislativo 755 (antigua Ley del Mercado de Valores) sobre las sociedades anónimas abiertas, cuya vigencia no había sido afectada por la nueva LMV. En sustitución de ellas, la LGS estableció una única categoría, denominada sociedad anónima abierta. Como lo explica Alfredo Ferrero Diez-Canseco,

"como miembros de la Comisión Reformadora pensábamos que buena parte de las normas establecidas por el Decreto Legislativo 672 para las sociedades de accionariado difundido podrían ser de utilidad para las sociedades anónimas abiertas, y que las normas contenidas en el Decreto Legislativo 755 también podrían ser aplicables para las sociedades anónimas de accionariado difundido, por lo que una propuesta interesante y necesaria era legislar ambas bajo un régimen único, ya que las características que distinguen a un tipo del otro no se reflejan con claridad suficiente como para considerarlos dos tipos sociales distintos" (Ferrero 1998, 30).

De esta manera, la LGS incorporó una única forma especial de sociedad anónima abierta, eliminando la figura de la sociedad de accionariado difundido como categoría distinta. Asimismo, pasó a regular, dentro de la legislación societaria, esta figura particular de sociedad por acciones, al igual que la sociedad anónima ordinaria y la sociedad anónima cerrada, dejando de estar dicha sociedad regulada en la legislación del mercado de valores. Este fue un importante avance metodológico de la LGS, al reivindicarse para el Derecho de Sociedades -y su cuerpo orgánico principal, la Ley General de Sociedades- la regulación de la sociedad anónima abierta, institución que hasta entonces había estado regulada en nuestro país en normas aisladas o en las leyes del mercado de valores.

Sin perjuicio de ello, el reordenamiento no fue completo. Como se verá más adelante, la LMV mantuvo ciertas normas que abordan materia societaria y que desde un punto de vista sistemático deberían estar contenidas en la Ley General de Sociedades, y la LGS no las derogó o ni las incorporó en su seno. Asimismo, a lo largo del tiempo se dictaron algunas disposiciones aisladas que regularon -lamentablemente, en algunos casos no de la mejor manera- algunos aspectos de gobierno corporativo de las sociedades anónimas cotizadas, invadiendo la competencia normativa de la Ley General de Sociedades.

\subsection{La Sociedad Anónima Abierta en la LGS}

\subsubsection{Definición}

La LGS define como sociedad anónima abierta a la que se encuentra en alguna de las siguientes situaciones:

a) Ha hecho oferta pública primaria de acciones o de obligaciones convertibles en acciones.

b) Tiene más de 750 accionistas.

c) Más del $35 \%$ de su capital pertenece a 175 o más accionistas, sin considerar a aquellos accionistas cuya participación en el capital no alcance al dos por mil o exceda del $5 \%$.

d) Se ha constituido como tal o todos los accionistas con derecho a voto han acordado por unanimidad la adaptación a dicho régimen.

De esta manera, la calidad de sociedad anónima se tiene por tres tipos de circunstancias. La primera es la apelación a la inversión del público por la vía de la oferta pública primaria de acciones. Como se sabe, la oferta pública primaria de acciones es aquella operación en la que el emisor se dirige al público en general o a determinado segmento de este, invitándolo a adquirir acciones de nueva emisión. El emisor es el receptor de los fondos invertidos. La sociedad recurre al mercado accionario, ofreciendo acciones al público a cambio de dinero, en lugar de endeudarse o recibir aportes de sus accionistas originales.

Nótese que no basta que la sociedad tenga sus acciones inscritas en el Registro Público del Mercado de Valores o en una Bolsa de Valores para que adquiera la calidad de sociedad anónima abierta, así dicha inscripción haya sido realizada por decisión de la propia sociedad. El que las acciones 


\section{José Antonio Payet Puccio}

sean objeto de oferta pública secundaria y se negocien en la Bolsa de Valores no determina, para la LGS, el carácter de abierta de la sociedad anónima. Asimismo, es de notar que para que la sociedad adquiera el carácter de abierta, debe realizar oferta pública primaria de acciones u obligaciones convertibles en acciones. Una oferta pública primaria de otro tipo de valores, por ejemplo, bonos corporativos ordinarios, no tiene ese efecto.

La segunda categoría de circunstancias que determinan el carácter de sociedad anónima abierta en la LGS es el grado de dispersión del accionariado. Este grado de dispersión se mide de dos formas. Una es el número total de accionistas. Si la sociedad tiene más de 750 accionistas, es una sociedad anónima abierta independientemente de la tenencia individual de cada uno de ellos. Como lo explica Enrique Elías Laroza, "se ha creído conveniente que si una sociedad tiene más de setecientos cincuenta accionistas debe organizarse como sociedad anónima abierta, pues se entiende que un número tan grande de socios responde al fenómeno disociador del capital social y del control de la empresa" (Elías 1998, 539).

El otro supuesto de dispersión del accionariado tiene ver con lo que llamaríamos el "capital flotante" de la compañía, es decir el porcentaje del capital que está en manos de pequeños accionistas y disperso en el mercado. La LGS exigió que ese porcentaje sea de $35 \%$ o más, y fijó la tenencia máxima individual a considerar para el efecto en $5 \%$. La lógica de este límite es clara, pues atiende a la porción en manos de accionistas que podríamos llamar minoritarios. No se entiende, sin embargo, la razón de no considerar para el cómputo del capital flotante a los accionistas cuyas tenencias individuales no alcanzan al dos por mil(12). En todo caso, como lo indicó Elias Laroza, "las cifras de los incisos 2 y 3 del artículo 249 son arbitrarias y responden a una decisión legislativa en la que se optó por señalar límites claros, que no dejan lugar a interpretaciones dudosas" (Elías 1998, 540).

Finalmente, la tercera categoría de situaciones en las que una sociedad tiene el carácter de abierta es cuando tiene dicha calidad por voluntad de sus socios. Para ello, sin embargo, la
LGS se aparta del principio de las mayorías y exige un acuerdo unánime, sea porque la sociedad se constituye como abierta (con lo que la forma societaria de abierta debe haber sido aceptada por todos los fundadores) o porque todos los socios, con acuerdo unánime, acordaron la adaptación a dicha forma. No se entiende claramente la razón de establecer un baremo tan riguroso para la adaptación de la sociedad a la forma de sociedad anónima abierta, sobre todo cuando dicha forma jurídica implicada no tiene en sí ninguna afectación de un derecho fundamental del accionista.

\subsubsection{Regulación sustantiva}

Definida de esta manera la sociedad anónima abierta, la regulación sustantiva contenida en la LGS que es aplicable a esta forma societaria se concentra en cuatro aspectos relevantes: la transparencia y la información; la negociabilidad de las acciones; el gobierno corporativo; y, el régimen de supervisión y control. En todos estos aspectos, el régimen de la sociedad anónima abierta varía respecto del de la sociedad anónima ordinaria. En lo demás, a la sociedad anónima abierta le son aplicables supletoriamente las normas de la sociedad anónima ordinaria.

\subsubsection{Información y transparencia}

En materia de información, interesa destacar, en primer lugar, el mandato contenido en el artículo 252 de la LGS en el sentido que la sociedad anónima abierta debe inscribir todas sus acciones en el Registro Público del Mercado de Valores. Como se sabe, el Registro Público del Mercado de Valores, regulado por la $L M V$, es el mecanismo operativo del régimen de transparencia de información que inspira la regulación del

(12) Si se pensó, como parece, que ese límite inferior marcaba una cifra monetaria poco significativa, el cálculo está equivocado El dos por mil de una empresa que vale 1,000 millones de soles o más -como es el caso de muchas sociedades anónimas cotizadas en Perú- es 2 millones o más. 
La Sociedad Anónima Abierta: algunas ideas para la reforma de su tratamiento legislativo The Open Stock Corporation: some ideas for the reform of its legislative treatment

mercado de valores. En este sentido, de acuerdo con los artículos 28 y 29 de la LMV, el registro de un valor obliga al emisor a informar al mercado, entre otras cosas, los hechos de importancia sobre sí y sobre los valores por él emitidos y a divulgar su información financiera no auditada trimestralmente y auditada anualmente. De esta forma, la inscripción de las acciones de la sociedad anónima abierta en el Registro Público del Mercado de Valores somete a dicha sociedad en forma plena al régimen de transparencia propio de las sociedades sujetas a la LMV.

Por otro lado, el artículo 261 de la LGS establecía originalmente que "la sociedad abierta debe proporcionar la información que le soliciten, fuera de junta, accionistas que representen no menos del $5 \%$ del capital con derecho a voto, siempre que no se trate de hechos reservados o de asuntos cuya divulgación pueda ocasionar daño a la sociedad". Se trata de un verdadero derecho de minoría calificada que, al momento de que se expidió la LGS, no existía para los accionistas de la sociedad anónima ordinaria. El artículo 52-A, introducido a la LGS por la Ley 29566, extendió este derecho a información fuera de junta para todas las sociedades anónimas, derogando el artículo 261 , de manera que en este aspecto la sociedad anónima abierta no se diferencia ahora de la ordinaria.

Finalmente, la LGS establece que las sociedades anónimas abiertas deben tener auditoría externa permanente. Este mandato es duplicativo del que contiene la LMV para las sociedades con valores inscritos en el Registro Público del Mercado de Valores. Sin perjuicio de ello, se trata de un elemento esencial del régimen de transparencia que sin duda es acertado y debe mantenerse.

3.1.4. Bursatilidad y libre negociación de las acciones El segundo tema en el que la LGS estableció disposiciones especiales para las sociedades anónimas abiertas es el de la inscripción en bolsa y la libre negociación de sus acciones.

Al respecto, en primer lugar, en cuanto a la emisión de nuevas acciones, la LGS buscó facilitar la negociación de acciones en el mercado primario. En este sentido, permitió que en la sociedad anónima abierta se excluya el derecho de suscripción preferente, tanto para los casos de aumento de capital en el que las nuevas acciones sean objeto de oferta pública como cuando fueran a ser objeto de una oferta privada. Siendo el derecho de suscripción preferente de gran importancia, pues permite al accionista evitar la dilución en casos en los que la sociedad requiere aumentar su capital por nuevos aportes, su aplicación crea importantes problemas prácticos al momento de realizar una oferta al público de acciones de nueva emisión, pues resulta incluso difícil estimar el importe del aumento de capital a efectuar si se requiere ofrecer las acciones primero a los accionistas, antes de poder ofrecerlas el público. Adicionalmente, el procedimiento de suscripción preferente, que implica la emisión, puesta a disposición y negociación de certificados de suscripción preferente, puede generar importantes demoras en la oferta primaria. Por todo ello, resulta acertada la disposición contenida en el artículo 259 de la LGS, en el sentido que puede acordarse que en un aumento de capital los accionistas no tendrán derecho de suscripción preferente. Esta disposición también eliminó acertadamente el requisito de aprobación de CONASEV que existía en el Decreto Legislativo 672 a este respecto, pero mantuvo el requisito de que "el aumento de capital no este destinado, directa o indirectamente, a mejorar la posición accionaria de alguno de los accionistas".

En cuanto a la negociación secundaria de las acciones, la LGS incluyó disposiciones para favorecer la libre circulación de las mismas. Nótese, en primer lugar, que al momento de entrar en vigencia la LGS, la inscripción de una acción en el Registro Público del Mercado de Valores obligaba también a su inscripción en Bolsa de Valores para su negociación en Rueda. Así, el texto original del artículo 83 de la LMV señalaba que "las acciones inscritas en el Registro deben también estarlo en una Rueda de Bolsa". De esta forma, el efecto original del mandato establecido en el artículo 252 de la LGS, en cuanto que todas las acciones de una sociedad anónima abierta deben estar inscritas en el Registro Público del Mercado de Valores, no solo era someter a la sociedad anónima abierta a las normas 


\section{José Antonio Payet Puccio}

de transparencia informativa de la LMV, sino que implicaba también que las acciones debían estar inscritas en Bolsa y ser susceptibles de negociación en Rueda de Bolsa.

En la visión de los autores de la LGS, la Sociedad anónima abierta es necesariamente una sociedad bursátil. Como lo señaló Enrique Normand Sparles en la exposición de motivos de la LGS: "la sociedad anónima abierta es una sociedad que está orientada, pensada, para transarse en el Mercado bursátil" (2009, XXXI). Pero esta ligazón entre la sociedad anónima abierta y la Bolsa de Valores quedó rota al modificarse, en el 2008, el artículo 83 de la LMV para establecer que es facultativa la inscripción en Bolsa de las acciones inscritas en el Registro Público del Mercado de Valores. Hoy una sociedad anónima abierta podría cumplir el requisito del artículo 252 de la LGS sin tener sus acciones inscritas en la Bolsa de Valores. Este es un cambio importante que generó un apartamiento de la lógica de un aspecto central del tratamiento de la sociedad anónima abierta en la LGS.

En el contexto en el que se dio la LGS, en el que las acciones de la sociedad anónima abierta debían estar inscritas en Bolsa, el artículo 254 de la LGS sancionó la invalidez de las estipulaciones del pacto social o del estatuto de una sociedad anónima abierta que establecieran limitaciones a la libre transmisibilidad de las acciones, restricciones a la negociación de las mismas, o derechos de preferencia a favor de accionistas o de la sociedad para adquirir las acciones en caso de transferencia. Igualmente, dispuso que "la sociedad abierta no reconoce los pactos de los accionistas que contengan las limitaciones, restricciones o preferencias antes referidas aun cuando se notifiquen o inscriban en la sociedad", estableciendo, en ese sentido, una excepción al mandato del artículo 8 de la LGS que prescribe que los convenios de accionistas comunicados a la sociedad la obligan "en todo cuanto le sea concerniente".

De esta manera, las limitaciones a la transferencia de acciones de una sociedad anónima abierta que estén contenidas en el estatuto o en el pacto social son nulas, mientras que las que están contenidas en un pacto de accionistas extra-estatutario son válidas, pero no resultan exigibles a la sociedad ni aunque se le comuniquen. Todo ello es enteramente lógico en el caso de acciones que se negocian en un mecanismo centralizado de negociación, como es la Rueda de Bolsa. Sin embargo, habiéndose dejado sin efecto la necesidad de que la sociedad anónima abierta mantenga sus acciones inscritas en Bolsa, la consistencia de estas disposiciones con el marco general de la negociabilidad de las acciones de este tipo de sociedades no resulta ya tan clara.

Los artículos 252 y 254 fueron modificados a los pocos años de vigencia de la LGS, por considerarse que los mismos tenían un alcance excesivo al referirse a todas las acciones de la sociedad anónima abierta, siendo posible que existiesen clases distintas de acciones, y que algunas de ellas estuviesen sujetas a reglas de preferencia o limitación de transferencia pre-existentes. De esa forma, se estableció que las reglas de obligación de listar y de libre transferibilidad antes aludidas, no eran de aplicación a "la clase o clases de acciones que estén sujetas a estipulaciones que limiten la libre transmisibilidad, restrinjan la negociación u otorguen derecho de preferencia para la adquisición de las mismas derivadas de acuerdos adoptados con anterioridad a la verificación de los supuestos previstos en los numerales 1, 2 y 3 del artículo 249 (...)". Se trata de casos de excepción, donde se reconoce la validez de restricciones originadas antes de que se configure la situación de hecho que determina el carácter de abierta de la sociedad.

Finalmente, la LGS, recogiendo lo que al respecto ya preveía el Decreto Legislativo 672 , otorgó derecho de separación a los accionistas disidentes "cuando una sociedad anónima abierta acuerda excluir el Registro Público del Mercado de Valores las acciones y obligaciones que tiene inscritas en dicho registro y ello determina que pierda la calidad de tal". La norma es técnicamente incorrecta, pues la exclusión de las acciones del Registro Público del Mercado de Valores no determina que una sociedad anónima pierda el carácter de abierta. Tal inscripción es una obligación de una sociedad abierta, no la razón por la cual la sociedad deviene en abierta. 
La Sociedad Anónima Abierta: algunas ideas para la reforma de su tratamiento legislativo The Open Stock Corporation: some ideas for the reform of its legislative treatment

La norma tendría que entenderse en el sentido que además de la exclusión de las acciones del Registro Público del Mercado de Valores, la sociedad deje de tener el grado de dispersión accionarial previsto en incisos 2 y 3 del artículo 249 de la LGS. Pero independientemente de ello, el derecho de separación resulta redundante en esta situación, ya que la exclusión de las acciones de una sociedad anónima abierta del Registro Público del Mercado de Valores, determinaría la obligación de realizar una oferta pública de compra por exclusión (OPC) de acuerdo con las normas de la LMV, oferta que cumple la misma función que el derecho de separación.

\subsubsection{Gobierno corporativo}

El tercer ámbito donde la LGS trajo disposiciones especiales para la sociedad anónima abierta es el del gobierno corporativo. Sin embargo, en esta materia la LGS se limitó fundamentalmente a establecer algunas disposiciones puntuales destinadas a facilitar el funcionamiento de la Junta General de Accionistas. Así, se estableció el derecho de accionistas que representen al menos el $5 \%$ de las acciones con derecho a voto (o de cualquier clase de acciones) a solicitar la convocatoria a Junta General (o a junta especial), reduciendo de esa forma, para la sociedad anónima abierta, el porcentaje de $20 \%$ que rige para la sociedad anónima ordinaria. Asimismo, se amplió el plazo de anticipación con el que debe publicarse el aviso de convocatoria, a 25 días (plazo que en las sociedades anónimas ordinarias es de diez o de tres días, dependiendo de la agenda de la junta), y se extendió a diez días el plazo de anticipación a la junta con el que deben estar inscritas las acciones en la matrícula de acciones (que en la sociedad anónima ordinaria es de dos días).

La LGS también modificó el quórum y la mayoría necesarias para que la Junta General de Accionistas pueda sesionar y adoptar acuerdos, reduciendo los porcentajes necesarios y eliminando, para la sociedad anónima abierta, el quórum y la mayoría calificados que existen en la sociedad anónima ordinaria para los acuerdos en la materias señaladas en el artículo 126 de la LGS, incluso en segunda convocatoria (quórum de $60 \%$ del capital suscrito con derecho a voto y mayoría de más de la mitad de las acciones suscritas con derecho a voto), los cuales, se estimó, podrían ser difíciles de alcanzar en algunas sociedades anónimas abiertas, dada la dispersión de su accionariado y la pasividad de sus accionistas minoritarios. En este sentido, el artículo 257 de la LGS estableció que para las referidas materias basta el
$50 \%$ del capital con derecho a voto para que la junta sesione en primera convocatoria y el $25 \%$ para que sesione en segunda el número de acciones que asista para que sesione en tercera convocatoria; y que los acuerdos se adoptan en todos los casos con la mayoría absoluta de las acciones representadas en la Junta, sin que se requiera cumplir con mayorías basadas en las acciones emitidas. Todo ello es bastante razonable, efectivamente facilita el funcionamiento de la Junta y no afecta la aplicación del principio de la mayoría. Sin embargo, adicionalmente la ley señaló que el estatuto no puede establecer mayorías ni quórum mayores, lo cual consideramos es innecesariamente restrictivo y contraproducente.

3.1.6. Atribuciones de la Superintendencia del Mercado de Valores

Por último, el cuarto aspecto en el cual la LGS regula de manera especial a la sociedad anónima abierta, es el de las facultades de la Superintendencia del Mercado de Valores sobre estas sociedades.

El artículo 253 de la LGS estableció originalmente que la CONASEV "está encargada de supervisar y controlar a la sociedad anónima abierta (...)", añadiendo que en ese sentido gozaba de facultades para, entre otras cosas, exigir la adaptación de la sociedad anónima ordinaria a sociedad anónima abierta y viceversa, exigir la entrega de información cuando sea solicitada por accionistas que representen al menos el 5\% del capital, y convocar a Junta General o especial de accionistas cuando sea solicitado en ejercicio de derechos de minorías. Posteriormente, se añadió la facultad de reglamentar las disposiciones relativas a estas sociedades contenidas en la LGS y de tipificar las infracciones y establecer las sanciones pertinentes.

Sin embargo, más recientemente, por Leyes 29782 y 30050 , se eliminaron algunas de 
José Antonio Payet Puccio

las principales facultades de la SMV sobre las sociedades abiertas, transfiriéndolas al Poder Judicial. Con ello, ciertamente, se fue en contra de lo que había sido la intención de la LGS al establecer la competencia de este organismo administrativo sobre la sociedad anónima abierta, competencia que se buscaba sea incluso sobre aspectos societarios. En palabras del doctor Enrique Norman Sparks, Presidente de la Comisión que redactó la LGS, "a esta clase de sociedad anónima se le ha incluido un control por la CONASEV, pero un control en sus aspectos societarios" (2009, 31). Lamentablemente, estas facultades fueron eliminadas y hoy la SMV se limita a las funciones más operativas de verificar la adaptación de la sociedad de y a la forma de sociedad anónima abierta y la publicación por dichas sociedades de listados de accionistas que no hayan recabado sus títulos accionarios o sus dividendos.

\subsection{Disposiciones Societarias en la LMV}

No obstante que con la expedición de la LGS y de la LMV se buscó reordenar el tratamiento legislativo de la sociedad anónima abierta en el seno de la legislación societaria, la Ley del Mercado de Valores aprobada por el Decreto Legislativo 861 introdujo también algunas disposiciones de carácter societario, invadiendo el terreno del Derecho de Sociedades, normas que hasta hoy sobreviven con algunas modificaciones.

Entre estas disposiciones, cabe mencionar el artículo 51 de la LMV, que establece ciertas normas aplicables a las sociedades que tengan valores (accionarios o no) inscritos en el Registro Público del Mercado de Valores. En esta disposición se estableció que "los directores y gerentes están prohibidos de recibir en préstamo dinero o bienes de la sociedad, o usar en provecho propio, o de quienes tengan con ellos vinculación, los bienes, servicios o créditos de la sociedad, sin contar con autorización del Directorio"; que "los directores y gerentes están prohibidos de valerse del cargo para, por cualquier otro medio y con perjuicio del interés social, obtener ventajas indebidas para sí o para las personas con las que tengan vinculación", y que para la celebración de actos y contratos que representen más del $10 \%$ del capital social con los directores o con sus cónyuges o parientes, se requiere la aprobación del Directorio; disponiendo que los beneficios que se recibieran con infracción de este artículo deben ser derivados a la sociedad, sin perjuicio de la responsabilidad por daños y perjuicios a que hubiera lugar.
Al igual que su antecedente del Decreto Legislativo 755, la norma es anti-técnica desde el punto de vista sistemático, pues la materia de los conflictos de interés y las transacciones con partes relacionadas estaba ya regulada en los artículos 170 y siguientes de la Ley General de Sociedades vigente en ese momento, y fue regulada asimismo en los artículos 179 y 180 de la actual LGS, para todas las sociedades anónimas, incluyendo tanto las que tienen valores inscritos en el Registro Público del Mercado de Valores, como las que no los tienen. Es posible que se requiera un estándar más exigente para ciertas transacciones en el caso de las sociedades con valores listados, pero ello puede lograrse sin mantener esa dualidad de regulación de la misma materia en la LMV y en la LGS y evitando la existencia de normas que se superponen y que en algunos casos resultan contradictorias e inconsistentes. Más apropiado sería incluir la regulación de las transacciones entre partes relacionadas en la LGS, al tratar sobre las sociedades anónimas abiertas, y realizar una referencia en la LMV que permita la aplicación de esta regla a otros emisores.

Es pertinente mencionar, en este punto, que mediante Ley 29720 se modificó el inciso c del artículo 51 de la LMV, para incorporar ciertos requisitos adicionales aplicables a las operaciones entre partes relacionadas. En concreto, se estableció que: "para la celebración de cada acto o contrato que involucre al menos el cinco por ciento de los activos de la sociedad emisora con personas naturales o jurídicas vinculadas a sus directores, gerentes o accionistas que directa o indirectamente representen más del diez por ciento del capital de la sociedad, se requiere la aprobación previa del Directorio, sin la participación del director que tenga vinculación" y que "en las transacciones en las cuales el accionista de control de la sociedad emisora también ejerza el control de la persona jurídica que participa como 
La Sociedad Anónima Abierta: algunas ideas para la reforma de su tratamiento legislativo The Open Stock Corporation: some ideas for the reform of its legislative treatment

contraparte en el respectivo acto o contrato sujeto a aprobación previa por el Directorio, se requiere adicionalmente la revisión de los términos de dicha transacción por parte de una entidad externa a la sociedad emisora". Es destacable la intención de incorporar una norma que regule las transacciones entre partes relacionadas en forma específica, incorporando elementos objetivos para prevenir la existencia de conflictos de interés (como el deber de abstención basado en un hecho objetivo, como la vinculación o el control, antes que en un elemento menos preciso, como el conflicto de intereses), y la incorporación del concepto de opinión de valor de parte de un tercero independiente (fairness opinión). Sin embargo, la norma adolece de algunos vacíos e imprecisiones que requieren ser corregidas ${ }^{(13)}$.

De otro lado, el artículo 85 de la LMV estableció también algunas disposiciones aplicables específicamente a las sociedades anónimas cuyas acciones de capital estén inscritas en el Registro del Mercado de Valores. En este sentido, permitió a dichas sociedades mantener acciones en cartera hasta por el $10 \%$ del capital. Esta posibilidad no estaba contemplada en la Ley General de Sociedades entonces vigente, y el Decreto Legislativo 672, que sí la autorizaba, fijaba un límite de apenas $1 \%$ del capital. Sin embargo, al darse la LGS, que sí incorporaba una regulación completa para la autocartera (artículos 104 y 105), se mantuvo en vigencia las disposiciones sobre la misma materia de la LMV, generándose nuevamente duplicidad e inconsistencia.

Adicionalmente, la LMV estableció que las sociedades cuyas acciones de capital estaban inscritas en el Registro del Mercado de Valores "deberán contar con una política de distribución de dividendos que fije expresamente los criterios para la distribución de utilidades". Esta disposición representó un avance importante, pues reemplazó la disposición que contenía el Decreto Legislativo 755 que establecía que CONASEV debía fijar un porcentaje de las utilidades que las sociedades con acciones de capital inscritas en el Registro del Mercado de Valores debían distribuir obligatoriamente ${ }^{(14)}$. Asimismo, estableció que dichas sociedades "no podrán acordar para sus directores una participación en las utilidades netas del ejercicio económico por encima del seis por ciento (6\%), salvo que tal circunstancia se divulgue como hecho de importancia (...)". Nuevamente, se trata de una disposición que tiene un efecto desregulador, frente a la disposición imperativa que contenía el Decreto Legislativo 755 en el sentido que las sociedades con acciones inscritas en el Registro Público del Mercado de Valores no podían dar a sus directores una participación superior al $10 \%$ en las utilidades de la sociedad. En ambos casos, se sustituyó acertadamente disposiciones que implicaban restricciones absolutas por normas de transparencia. Sin embargo, desde el punto de vista sistemático, se reguló aspectos societarios en la LMV.

La LMV incluyó también disposiciones en materia de emisión de obligaciones (artículos 86 y siguientes) y de certificados de suscripción preferente (artículos 101 y siguientes) que resultaron a final de cuentas duplicativas de las disposiciones que sobre la misma materia trajo la LGS.

\subsection{Otras normas societarias en disposiciones aisladas}

Para concluir esta revisión del tratamiento de la sociedad anónima abierta en nuestra legislación, no puede dejar de mencionarse las disposiciones aisladas en materia societaria contenidas en Ley 29720 y la Ley 30050 aplicables a las sociedades con acciones listadas en Bolsa.

Una de ellas se refiere al intento legislativo de establecer una absurda responsabilidad objetiva a cargo del Directorio de la sociedad anónima. Luego de algunas idas y venidas

(13) Véase generalmente, José Antonio Payet, "Transacciones entre partes relacionadas," IUS ET VERITAS 48 (julio 2014 ): 152-78.

(14) Lamentablemente, la LGS mantuvo una disposición inconveniente en el artículo 231 señalando que en caso de decidirlo así accionistas que representan al menos el $20 \%$ del capital con derecho a voto, la sociedad estaba obligada a distribuir como dividendos el $50 \%$ de la utilidad distribuible. 


\section{José Antonio Payet Puccio}

legislativas, al final lo que quedó vigente fue una disposición (artículo 3 de la Ley 29720 modificado por la Ley 30050) que señala lo siguiente:

"los directores de los emisores con acciones representativas del capital social inscritas en las Bolsas de Valores son responsables civilmente ante la sociedad y los accionistas por los daños y perjuicios que causen por adoptar acuerdos que no privilegien el interés social sino sus propios intereses o los de terceros relacionados, respecto de transacciones en las que se presenten las siguientes características: 1. Una de las partes intervinientes es la sociedad con acciones representativas del capital social inscritas en las Bolsas de Valores; 2. El accionista de control de la sociedad señalada en el inciso precedente ejerce además el control de la persona jurídica que participa como contraparte en una determinada transacción; y, 3. La transacción no se ajusta a precios, condiciones o términos que prevalezcan en el mercado al tiempo de su aprobación e involucra al menos el diez por ciento (10\%) de los activos de la sociedad emisora (...)".

Como lo señalé hace algún tiempo, la norma "parece establecer, para un subconjunto de sociedades anónimas, las listadas, una regla de responsabilidad menos exigente que la prevista con carácter general para todas las sociedades anónimas en el artículo 180 de la Ley General de Sociedades, ya que para que se gatille la responsabilidad bajo el artículo 3 de la Ley 29720 modificado se necesita además que se cumplan todas las condiciones adicionales previstas en dicho artículo" (Payet 2014, 177-8). Indiqué además, en cuanto a la pretendida responsabilidad objetiva, que "si uno cae en la cuenta de que lo que la norma sanciona es una infracción al deber de lealtad (adoptar acuerdos que no cautelen el interés social sino los intereses propios del director o los de terceros relacionados) no cabe sino concluir que el dolo es parte necesaria de la configuración misma de la infracción" (Payet 2014, 177-8).

Mucho más acertada es la disposición contenida en el artículo 4 de la Ley 29720, en la que se refuerza significativamente las disposiciones que permiten a accionistas ejercer directamente la pretensión social de responsabilidad en el caso de sociedades con acciones inscritas en Bolsa de Valores. Esta norma reduce de un tercio a 10\% del capital la participación accionaria exigida a los demandantes y elimina el requisito previo de que la Junta General haya adoptado una decisión de no proceder a ejercer la pretensión. Dicha disposición además, incluye la facultad de los demandantes de exigir judicialmente al Directorio "de forma genérica todos los documentos relacionados al acto o decisión que se investiga"(15) y la obligación de los directores demandados restituir los beneficios que se hubiera obtenido con la transacción que dé lugar a responsabilidad, de ser el caso, como parte de la indemnización de daños y perjuicios. Como tuve la oportunidad de comentar hace varios años, "el principal problema de la acción social de responsabilidad reside en las exigencias que la ley impone para su ejercicio" (Payet 2003, 90). La disposición contenida en el artículo 4 de la Ley 29720 contribuye claramente a solucionar este problema.

\subsection{El mapa de la regulación actual}

A pesar de que en la visión de los autores de la LGS el panorama societario se había logrado ordenar en tres modelos de sociedad anónima, la sociedad anónima ordinaria, la sociedad anónima cerrada y la sociedad anónima abierta, la realidad es que incluso desde el momento mismo de la entrada en vigencia de la LGS existían ya algunas sociedades anónimas sujetas a normas societarias especiales, no en función de sus actividades (como podría ser en el caso de los bancos o las compañías de seguros), sino en función de la superposición y descoordinación existente entre la LMV y la LGS. Y ese proceso se ha agravado en el tiempo.

En este sentido, fuera de la sociedad anónima cerrada, hoy podemos distinguir la siguiente

(15) La norma dice que esta solicitud se realiza en el proceso judicial. Más apropiado hubiera sido incluir una norma que permita expresamente formularla en vía de prueba anticipada. 


\section{La Sociedad Anónima Abierta: algunas ideas para la reforma de su tratamiento legislativo The Open Stock Corporation: some ideas for the reform of its legislative treatment}

tipología de sociedades anónimas, de acuerdo con la normativa societaria que les es aplicable en función de su dispersión accionaria o conexión con el mercado público de valores:

Para dimensionar el universo sobre el que recae esta regulación, resulta útil revisar algunas cifras que la Superintendencia del Mercado de Valores proporcionó al
Grupo de Trabajo conformado por el Gobierno para revisar la Ley General de Sociedades en el año 2014. Según esta información, a esa fecha existían doscientos setenta y un sociedades con valores inscritos en el Registro Público del Mercado de Valores, de las cuales doscientos siete tenían acciones inscritas en dicho registro. Si bien no tengo información

\begin{tabular}{|c|c|}
\hline Clase de Sociedad & Normas Societarias Aplicables \\
\hline $\begin{array}{l}\text { Sociedad anónima ordinaria sin valores inscritos en el Registro } \\
\text { Público del Mercado de Valores }\end{array}$ & Normas sobre sociedad anónima ordinaria de la LGS. \\
\hline $\begin{array}{l}\text { Sociedad anónima ordinaria con valores no accionarios } \\
\text { inscritos en el Registro del Mercado de Valores }\end{array}$ & $\begin{array}{l}\text { Normas sobre sociedad anónima ordinaria de la LGS. } \\
\text { Normas sobre transacciones entre partes relacionadas establecidas en el artículo } 51 \text { de } \\
\text { la LMV. }\end{array}$ \\
\hline $\begin{array}{l}\text { Sociedad anónima ordinaria con acciones inscritas en el } \\
\text { Registro Público del Mercado de Valores }\end{array}$ & $\begin{array}{l}\text { Normas sobre sociedad anónima ordinaria de la LGS. } \\
\text { Normas sobre transacciones entre partes relacionadas establecidas en el artículo } 51 \text { de } \\
\text { la LMV. } \\
\text { Normas sobre política de dividendos y participación de directores en las utilidades estab- } \\
\text { lecidas en el artículo } 85 \text { de la LMV. }\end{array}$ \\
\hline $\begin{array}{l}\text { Sociedad anónima ordinaria con acciones inscritas en el Reg- } \\
\text { istro Público del Mercado de Valores y en la Bolsa de Valores }\end{array}$ & $\begin{array}{l}\text { Normas sobre sociedad anónima ordinaria de la LGS. } \\
\text { Normas sobre transacciones entre partes relacionadas establecidas en el artículo } 51 \text { de } \\
\text { la LMV. } \\
\text { Normas sobre política de dividendos y participación de directores en las utilidades estab- } \\
\text { lecidas en el artículo } 85 \text { de la LMV. } \\
\text { Normas sobre acciones en cartera establecidas en el artículo } 84 \text { de la LMV. } \\
\text { Normas sobre responsabilidad de directores establecida en el artículo } 3 \text { de la Ley } 29720 \text {. } \\
\text { Normas sobre pretensión social de responsabilidad establecidas en el artículo } 4 \text { de la Ley } \\
29720 \text {. } \\
\text { Normas especiales sobre certificados de suscripción preferente establecidos en los artículos } \\
101 \text { y siguientes de la LMV. }\end{array}$ \\
\hline $\begin{array}{l}\text { Sociedad anónima abierta con acciones inscritas en el Registro } \\
\text { Público del Mercado de Valores pero no en la Bolsa de Valores }\end{array}$ & $\begin{array}{l}\text { Normas sobre sociedad anónima abierta de la LGS. Aplicación supletoria de las normas } \\
\text { sobre sociedad anónima ordinaria de la LGS. } \\
\text { Normas sobre transacciones entre partes relacionadas establecidas en el artículo } 51 \text { de } \\
\text { la LMV. } \\
\text { Normas sobre política de dividendos y participación de directores en las utilidades estab- } \\
\text { lecidas en el artículo } 85 \text { de la LMV. }\end{array}$ \\
\hline $\begin{array}{l}\text { Sociedad anónima abierta con acciones inscritas en el Registro } \\
\text { Público del Mercado de Valores y en la Bolsa de Valores. }\end{array}$ & $\begin{array}{l}\text { Normas sobre sociedad anónima abierta de la LGS. Aplicación supletoria de las normas } \\
\text { sobre sociedad anónima ordinaria de la LGS. } \\
\text { Normas sobre transacciones entre partes relacionadas establecidas en el artículo } 51 \text { de } \\
\text { la LMV. } \\
\text { Normas sobre política de dividendos y participación de directores en las utilidades estab- } \\
\text { lecidas en el artículo } 85 \text { de la LMV. } \\
\text { Normas sobre acciones en cartera establecidas en el artículo } 84 \text { de la LMV. } \\
\text { Normas sobre responsabilidad de directores establecida en el artículo } 3 \text { de la Ley } 29720 . \\
\text { Normas sobre pretensión social de responsabilidad establecidas en el artículo } 4 \text { de la Ley } \\
29720 \text {. } \\
\text { Normas especiales sobre certificados de suscripción preferente establecidos en los artículos } \\
101 \text { y siguientes de la LMV. }\end{array}$ \\
\hline
\end{tabular}




\section{José Antonio Payet Puccio}

al respecto, puedo suponer razonablemente que la mayoría de esos doscientos siete emisores con acciones inscritas en el Registro Público del Mercado de Valores tienen también inscritas en sus acciones en la Bolsa de Valores. Finalmente, existían cincuenta y cinco sociedades anónimas abiertas, de las cuales cincuenta y uno tenían sus acciones inscritas en el Registro Público del Mercado de Valores y en Bolsa de Valores y solo cuatro las tenían inscritas en el Registro Público del Mercado de Valores pero no en Bolsa.

\section{La necesaria reforma de la sociedad anónima abierta}

Considero que es indispensable que se realice una revisión profunda del tratamiento de la sociedad anónima abierta en nuestro Derecho de Sociedades y en la Ley del Mercado de Valores.

El tratamiento actual de esta figura en nuestra legislación está desactualizado frente a las modernas corrientes en materia de gobierno corporativo. Es asistemático, pues en lugar de haberse solucionado los problemas de superposición entre la LMV y la LGS, estos problemas se han agravado en el tiempo. Finalmente, se trata de un tratamiento que ha sido objeto de modificaciones asiladas en el tiempo, las que, como regla general, han roto la lógica de instituciones existentes y establecido incluso en ciertos casos reglas absurdas o contradictorias. Producto de este desorden normativo, además de la sociedad anónima cerrada y la sociedad anónima ordinaria que no tienen contacto con el mercado público de valores, existen hasta cinco categorías de sociedades anónimas sujetas a diferente tratamiento en materia societaria, cuya normativa es desordenada, asistemática y carente de racionalidad.

Han pasado alrededor de veinte años desde que se dieron las normas que hoy forman la base fundamental del tratamiento legislativo de la sociedad anónima abierta en nuestro Derecho. Y si bien tanto la LMV como la LGS eran en general normas modernas y técnicamente acertadas al darse, a fines de los años 1990, no es menos cierto que el mundo del Derecho de Sociedades en materia de sociedades anónimas abiertas ha cambiado mucho en estos veinte años y que nuestro Derecho no ha seguido esta evolución.

Es importante observar que la LGS y la LMV se dan antes de que se inicie el movimiento legislativo a nivel del Derecho Comparado, en el sentido de incorporar reglas de transparencia y de buen gobierno corporativo en las legislaciones aplicables a las sociedades abiertas. Como se ha visto, la LGS se expide en diciembre de 1997 y la LMV se da en octubre de 1996. El Cadbury Report, el primero de los grandes códigos de cumplimiento voluntario en materia de gobierno corporativo, se había publicado en el Reino Unido en $1992^{(16)}$ estableciendo la regla comply or explain, pero el concepto de gobierno corporativo, e incluso la expresión misma, no se habían extendido a los países de Derecho Civil. El caso Enron aún no había estallado, y pasarían varios años antes que se dicte la Ley Sarbanes-Oxley en los Estados Unidos en julio del $2002^{(17)}$ y que se publique el Informe Winter en la Union Europea ${ }^{(18)}$.

De entonces hasta ahora, la normativa aplicable a las sociedades anónimas abiertas ha experimentado una verdadera revolución en la mayoría de los mercados desarrollados e incluso en mercados de menos desarrollo relativo como México o Chile. Los casos Enron, Worldcom, Parmalat, entre otros, generaron un movimiento legislativo muy importante en pro de la transparencia y el buen gobierno corporativo de las sociedades cotizadas, movimiento que vio reforzado aún más a raíz de la crisis financiera del 2008. Como lo ha

(16) Véase The report of the committee on the financial aspects of corporate governance, Londres, diciembre 1992. Disponible en: www.ecgi.org/codes/documents/cadbury.pdf

(17) Sarbanes-Oxley Act of 2002, Pub. L. No. 107-204, 116 Stat. 745.

(18) Véase Report of the High Level Group of Company Experts on a Modern Regulatory Framework for Company Law in Europe, Bruselas, 4 de Noviembre de 2002. 


\section{La Sociedad Anónima Abierta: algunas ideas para la reforma de su tratamiento legislativo The Open Stock Corporation: some ideas for the reform of its legislative treatment}

señalado Kalus Hopt, "la reforma corporativa, de las Bolsas de valores y del mercado de capitales ha sido en gran parre generada por los escándalos corporativos; y esto es tambien cierto para el gobierno corporativo" (Hopt 2011, 17). Asimismo, como lo apunta también Hopt, el efecto de recepción del derecho extranjero ha sido muy importante, destacándose sobre todo la influencia de la Ley Sarbanes-Oxley en muchos mercados $(2011,19)$. Como lo explica Fernández-Pérez, hablando de la experiencia española, la configuración del estatuto jurídico de la sociedad cotizada "ha sido el resultado de la importante evolución del Derecho societario, en el que ha venido jugando un papel decisivo el movimiento de reforma centrado en la gobernanza de las sociedades, denominado Corporate governance (...)" (Fernández-Pérez 2011, 3268).

Los pocos intentos de modernización de nuestro Derecho de Sociedades en estos últimos 20 años han sido lamentablemente inadecuados e insuficientes. Se ha tratado de modificaciones puntuales en materia de acceso a información, transacciones entre partes relacionadas y responsabilidad del Directorio, que distan mucho de ser la reforma orgánica, técnica y completa que requiere nuestro Derecho de Sociedades en materia de la sociedad anónima abierta. El desarrollo de nuestro mercado de capitales, el que las empresas puedan recurrir al mercado accionario para financiar sus actividades, el que el público pueda confiar sus ahorros a estas sociedades y el que las sociedades peruanas se gobiernen eficientemente $y$ con transparencia, depende de muchos factores. El Derecho de Sociedades es uno de los más importantes. Pero para ello debemos entender el Derecho de Sociedades como un Derecho vivo, que responda a la realidad y sirva como instrumento de acumulación de capital, de canalización de inversiones, de creación de riqueza, y de promoción del desarrollo económico. La sociedad anónima abierta debe ser regulada para servir como instrumento de este proceso, mirando las experiencias exitosas a nivel internacional y buscando elevar los estándares de nuestro mercado de capitales. Resulta, a este efecto, enteramente pertinentes y absolutamente oportunas las recomendaciones hechas por el maestro Joaquín Garrigues en el sentido de mirar los problemas reales para buscar las soluciones jurídicas a la problemática de las sociedades anónimas ${ }^{(19)}$.

La reforma que considero necesario se emprenda debe construir sobre la regulación actual de la sociedad anónima abierta en la LGS y en la LMV, dando organicidad y sistemática al tratamiento de esta modalidad de sociedad anónima, incorporando las lecciones propias de la experiencia práctica de estos casi 20 años de vigencia, corrigiendo algunos errores, y acogiendo los avances más relevantes habidos en esta materia a nivel internacional. A este respecto, además, es importante tener en cuenta que la regulación de la sociedad anónima abierta, como toda regulación, debe tener como finalidad el solucionar problemas concretos que este modelo de organización presenta (en esencia, los costos de agencia identificados por la literatura económica), y debe ser proporcional, sin ir más allá de lo necesario para solucionar esos problemas. Como lo ha señalado en el Informe del Grupo de Reflexión sobre el Futuro del Derecho de Sociedades en la Unión Europea,

"Las compañías listadas sólo deben estar sujetas a regulación especial comparadas con sus competidoras no listadas cuando ello se justifica por sus características

(19) Escribía el maestro Garrigues (en 1933): “En el campo, cada día más extenso, de la sociedad anónima, he preferido alejarme de la seca construcción jurídica para elegir un tema de amplias perspectivas, de visión panorámica del ordenamiento jurídico de la sociedad anónima, estudiando el Derecho vivo en vez del Derecho inerte literalizado en los Códigos. Para esta preferencia he atendido a dos razones principales: primeramente, la de reconocer que en el Derecho de sociedades mercantiles, el subsuelo económico está más cerca de la superficie que en ningún otro sector jurídico (...) En segundo término, pesa sobre mi la convicción de que no es posible acometer la reforma del Derecho de sociedades anónimas sumergiéndose en la espesura de las disposiciones legales aisladas y perdiendo de vista los puntos cardinales, los problemas fundamentales determinantes de toda racional reforma". Joaquín Garrigues, Nuevos Hechos, Nuevo Derecho de Sociedades Anónimas (Madrid: Civitas, 1998), 4-5. 
José Antonio Payet Puccio

especiales y no deberían ser objeto de regulación adicional más allá de eso (...) Es un error considerar a las compañías listadas como compañías "publicas" como si pertenecieran al dominio público, son compañías privadas porque son de propiedad privada y sólo deberían ser objeto de regulación especial cuando ello se justifica por el hecho de que sus valores están listados o son de otra forma objeto de negociación entre el público" $(2011,10)$.

A continuación apunto algunos elementos que considero deben tomarse en consideración para esta reforma. No pretendo realizar una enumeración exhaustiva de los temas a revisar ni menos aún efectuar una propuesta definitiva o completa. Se trata, más bien, de algunas ideas respecto de temas que creo revisten particular importancia y que no se encuentran adecuadamente tratados hoy a nivel legislativo.

\subsection{La tipología de sociedades}

La primera cuestión que creo debe plantearse al reformar la sociedad anónima abierta es la determinación del universo al cual debe aplicarse el estatuto jurídico especial, es decir, la definición de sociedad anónima abierta. Al respecto, creo que hay dos cuestiones a determinar. La primera es la cuestión de si toda sociedad cuyas acciones se negocien en Bolsa debe considerarse como sociedad anónima abierta, o si se debe exigir algún requisito adicional. La segunda es si debe existir una obligación de tener acciones inscritas en Bolsa (o, de ser el caso, en el Registro del Mercado de Valores) para las sociedades que tengan algún grado determinado de dispersión de accionariado.

Fue acertada la opción de la LGS por dividir el universo de las sociedades anónimas en tres tipos base, la sociedad anónima cerrada, la sociedad anónima ordinaria y la sociedad anónima abierta. Sin embargo, si bien la LGS consideró que la sociedad anónima abierta debía necesariamente ser una sociedad bursátil (de allí el mandato del artículo 252, que como se ha visto equivalía a ordenar la inscripción en Bolsa de las acciones de la sociedad anónima abierta), esa misma relación no se aplicaba inversamente. En otras palabras, si bien toda sociedad anónima abierta debía tener sus acciones inscritas en Bolsa, no toda sociedad cuyas acciones estuvieran inscritas en Bolsa era considerada como abierta. Para ser la sociedad abierta tenía que encontrarse en una de las tres categorías explicadas anteriormente: haber hecho oferta pública primaria, tener un determinado grado de dispersión de capital o tratarse de un caso de voluntad unánime de los accionistas.

En mi opinión, el estatuto jurídico de la sociedad anónima abierta debe ser aplicable a todas las sociedades domiciliadas en el Perú cuyas acciones representativas de capital social estén inscritas en la Bolsa de Valores para su negociación secundaria. Considero que la inscripción de las acciones de una sociedad en la Bolsa de Valores implica una definición de la vocación de la sociedad por la apertura de su capital y que, consiguientemente, las normas societarias que le sean aplicables deben ser las propias de las sociedades con esa vocación, independientemente del grado de dispersión de su accionariado. Esta es, por ejemplo, la opción de la Ley de Sociedades de Capital de España de 2010, que regula a las que denomina sociedades anónimas cotizadas como un tipo especial de sociedad anónima, definiéndolas en su artículo 495 como "las sociedades anónimas cuyas acciones están admitidas a cotización en un mercado secundario oficinal de valores"(20). Es también la opción de México, cuya Ley

(20) Como señala Nuria Fernández-Pérez: "Esa apelación al ahorro público con la puesta en el mercado de sus acciones resulta decisiva a la hora de determinar la existencia de un régimen jurídico distinto respecto de las sociedades anónimas cotizadas y no cotizadas. Y ello porque determina que, junto a los clásicos intereses protegidos por el Derecho de Sociedades, que son básicamente la protección de los socios y de los terceros acreedores, deban unirse otros de carácter público, como son el buen funcionamiento del mercado de capitales del que la sociedad cotizada forma parte y la protección de los intereses jurídicos de los inversores, tanto reales como potenciales que acuden el mercado para adquirir acciones, convirtiéndose de ese modo en socios de la sociedad". Nuria Fernández-Pérez, "Sociedades Anónimas Cotizadas," en Comentario de la Ley de Sociedades de Capital, coords. Ángel Rojo y Emilio Beltrán. Tomo II (Pamplona: Civitas, 2011), 3267. 
La Sociedad Anónima Abierta: algunas ideas para la reforma de su tratamiento legislativo The Open Stock Corporation: some ideas for the reform of its legislative treatment

del Mercado de Valores de 2005 regula en forma específica a las denominadas sociedades anónimas bursátiles, a las que define como "las sociedades anónimas cuyas acciones representativas del capital social o títulos de crédito que representen dichas acciones, se encuentren inscritas en el Registro"(21).

Es cierto que el mercado de valores peruano presenta algunas peculiaridades que hacen que existan un número relativamente grande de sociedades anónimas cuyas acciones están inscritas en la Bolsa de Valores de Lima, pero que en la práctica no están sujetas a negociación ni tienen un número relevante de accionistas minoritarios. Así, existen ciertos incentivos fiscales para que una compañía de capital cerrado inscriba sus acciones en la Bolsa de Valores, sin ninguna pretensión de abrir su capital(22). A ello, se suma el que ni la regulación de la SMV ni los requisitos de listado de la Bolsa de Valores de Lima exigen un mínimo de capital flotante ni de liquidez, ni menos aún la realización de una oferta pública inicial de acciones (IPO), para que una sociedad pueda inscribir sus acciones en la Bolsa de Valores para su negociación en Rueda de Bolsa. Estos factores llevan a que, como se ha dicho, exista un número importante de emisores listados sin liquidez. Sin embargo, ello a mi criterio no obsta para mantener la identidad entre sociedad abierta y sociedad listada. Se trata de situaciones de excepción puntuales en las que, además, la aplicación de la regulación de la sociedad anónima abierta no debería generar ningún efecto adverso ni ningún costo significativo adicional al ya asumido por el listado, y más bien puede generar beneficios por el lado de mayor transparencia y mejor gobierno corporativo(23).
Así pues, a mi criterio, la sociedad anónima abierta debe ser definida como la sociedad cuyas acciones están inscritas en una Bolsa de Valores para su negociación secundaria. Ello lleva a plantearse una segunda cuestión en el sentido si debe ser obligatorio para una sociedad anónima inscribir sus acciones en una Bolsa de Valores por razones vinculadas a la dispersión de su accionariado, tales como el número de accionistas que tiene o el porcentaje de su capital que está en manos de accionistas minoritarios. A mi criterio, la respuesta ha de ser negativa. La sociedad anónima sujeta al estatus normativo de la sociedad anónima abierta debe ser aquella que opta por someterse a este estatuto jurídico al poner sus acciones en el mercado púbico de valores. La dispersión del accionariado no debe ser causa de que la sociedad devenga sometida al estatus jurídico de la sociedad anónima abierta, independientemente de la voluntad de sus socios, como actualmente lo es según los incisos 2 y 3 del artículo 249 de la LGS.

Naturalmente, la voluntad de los socios que dé lugar a la aplicación de este estatuto jurídico especial debe ser, en primer lugar, el resultado de un acuerdo mayoritario a nivel de la sociedad. Al respecto, considero que es necesario cubrir el vacío existente

(21) Se refiere al Registro Nacional de Valores de México, equivalente a nuestro Registro Público del Mercado de Valores. La Ley del Mercado de Valores de México regula los principales aspectos societarios de las sociedades anónimas bursátiles, incluyendo su administración, los deberes de diligencia y lealtad de sus administradores, las asambleas de accionistas y los derechos de los socios y la emisión de sus acciones, etcétera.

(22) La legislación tributaria ha establecido que para que una operación de enajenación de valores realizada por una persona no domiciliada se considere efectuada en el Perú a efectos de poder aplicar la tasa de $5 \%$ del Impuesto a la Renta a las ganancias de capital se requiere que los valores estén inscritos en el Registro Público del Mercado de Valores y que dicha operación se realice a través de un mecanismo centralizado de negociación en el Perú.

(23) De otro lado, existe la situación de las empresas del sistema financiero, el sistema de seguros y las administradoras privadas de fondos de pensiones, cuyas legislaciones privativas las obligan a mantener sus acciones inscritas en una Bolsa de Valores. Esta regulación debiera ser modificada, pues no existe justificación para obligar a una sociedad a inscribir sus acciones en una Bolsa de Valores si ni la sociedad ni sus accionistas tienen voluntad de que sus acciones sean objeto de oferta pública. En todo caso, si la intención es la de obligar a estas sociedades a cumplir los deberes de información previstos en la LMV, ello puede hacerse mediante un mandato directo en el sentido que tales acciones deben inscribirse en el Registro Público del Mercado de Valores pero no requieren estar inscritas en una Bolsa de Valores. 


\section{José Antonio Payet Puccio}

a nivel de la LGS respecto del cuál es el órgano societario competente para acordar la inscripción y la exclusión de las acciones de la Bolsa de Valores. Dada la trascendencia del listado, en mi opinión, dicho órgano debe ser la Junta General de Accionistas. Pero considero que, en adición a ello, el sometimiento de la sociedad al estatuto de la sociedad anónima abierta debe también poder ser el resultado del ejercicio de un derecho de minoría calificada. En este sentido, considero que es acertada y debe mantenerse la solución establecida actualmente en el artículo 25 de la LMV, que prescribe que "accionistas que representen cuando menos el veinticinco por ciento $(25 \%)$ del capital social del emisor pueden solicitar la inscripción de sus acciones" y que "en tal caso, la inscripción se limita a las acciones pertenecientes a los peticionarios, las que deberán quedar comprendidas en una nueva clase". De esta manera, una sociedad anónima podrá inscribir sus acciones en la Bolsa de Valores y adquirir el carácter de una sociedad anónima abierta por decisión mayoritaria adoptada por su Junta General de Accionistas o por el ejercicio de un derecho de minoría calificada otorgado a accionistas que representen al menos el $25 \%$ del capital social. En este último caso la inscripción se limita a las acciones de los solicitantes, que quedan separadas en una clase especial, pero la sociedad como un todo queda sometida al régimen indivisible de la sociedad anónima abierta.

Al identificarse la calidad de sociedad bursátil con la de sociedad anónima abierta, se solucionaría también el inconveniente existente actualmente, de falta de claridad respecto de la forma como una sociedad que realiza una oferta pública primaria puede dejar de ser sociedad anónima abierta. De esta forma, si la sociedad excluye sus acciones del mercado bursátil, dejará de ser considerada como una sociedad anónima abierta. Con ello se cubre el vacío normativo que existe en la LGS en el sentido que si una sociedad anónima que realiza oferta pública primaria adquiere la calidad de sociedad anónima abierta en forma permanente, aunque se desliste posteriormente; y se soluciona también la situación de sociedades que por más que excluyen sus acciones del mercado bursátil siguen teniendo la condición de abiertas por tener más de 750 accionistas. Para promover el mercado accionario no solo es necesario establecer mecanismos que faciliten a las empresas la oferta pública de acciones y la entrada a la Bolsa de Valores, sino que también es necesario tener reglas claras que permitan la salida del mercado bursátil cuando ello corresponde.

4.2. Ubicación sistemática de la regulación La sociedad anónima abierta, siendo una sociedad anónima cuyas acciones se negocian en el mercado público de valores, se ubica normativamente bajo el ámbito de aplicación de dos conjuntos normativos, la legislación societaria propiamente dicha y la legislación del mercado de valores. Como lo dice Alberto Tapia Ermida, "el régimen jurídico de estas SSAA cotizadas o bursátiles se caracteriza porque están permanentemente sometidas a una doble normativa: la societaria (SA y RRM) y la mobiliaria (LMV y normas de desarrollo)" (2010, 9).

Sin embargo, considero que el estar estas sociedades sometidas a esta doble normativa no debe impedir distinguir claramente la naturaleza de las materias objeto de regulación, naturaleza que debe marcar la ubicación sistemática de las disposiciones correspondientes. En este sentido, las disposiciones que tengan que ver con la categorización de la sociedad anónima como abierta, el gobierno de la sociedad, la conformación y el funcionamiento de sus órganos, los derechos, deberes y responsabilidades de sus socios y administradores, y otros aspectos similares, deben estar recogidas en la Ley General de Sociedades. En cambio, los aspectos que tengan que ver con la relación que la sociedad como emisor tiene con el mercado de valores en general, con la Bolsa de Valores y con el órgano supervisor del mercado, deben recogerse en la Ley del Mercado de Valores. Estos aspectos comprenden materias como los requisitos de inscripción y exclusión de los valores y de su oferta, el régimen de la oferta 
La Sociedad Anónima Abierta: algunas ideas para la reforma de su tratamiento legislativo The Open Stock Corporation: some ideas for the reform of its legislative treatment

primaria y secundaria, el régimen de la negociación de los valores, las normas sobre transparencia y el régimen general de información (disclosure), etcétera(24).

Por esta razón, las disposiciones que abordan materia societaria de las sociedades anónimas abiertas, sociedades con acciones inscritas en el Registro Público del Mercado de Valores y sociedades con acciones inscritas en Bolsa de Valores, actualmente contenidas en la Ley del Mercado de Valores deben ser reubicadas en la Ley General de Sociedades. Esto incluye las disposiciones en materia de conflictos de interés y transacciones entre partes relacionadas contenidas en el inciso c del artículo 51 (los incisos a y b del artículo 51 considero que deberían ser derogados, pues repiten mandatos ya establecidos en forma más adecuada en la LGS), las normas sobre política de dividendos y participación de los directores en las utilidades contenidas en el artículo 85 (esta última podría derogarse, pues la revelación como hecho de importancia de las retribuciones del Directorio debería hacerse en cumplimiento del deber general de informar de los emisores bajo la LMV, por razones de elemental transparencia) y las normas sobre certificados de suscripción preferente establecidas en los artículos 101 y siguientes. Lo mismo debe hacerse con la disposición sobre pretensión de responsabilidad de directores contenida en el artículo 4 de la Ley 29720 (el artículo 3 de la misma ley debería ser derogado, por los graves defectos que presenta). En caso que haya algunas disposiciones aplicables a las sociedades anónimas abiertas cuya aplicación quiera extenderse a otros emisores de valores de oferta pública -como podría ser el caso de las disposiciones en materia de transacciones entre partes relacionadas actualmente contenidas en el inciso c del artículo 51 de la LMV- ello debería hacerse con una norma de remisión contenida en la Ley del Mercado de Valores.

\subsection{Conformación y funciones del Directorio}

El aspecto donde se han dado los cambios más importantes en la legislación en materia de gobierno corporativo en los últimos años, es en las disposiciones relacionadas al funcionamiento del Directorio ${ }^{(25)}$. Es cierto que la figura protagónica del Directorio en el gobierno corporativo de las sociedades cotizadas no es ninguna novedad. De hecho, el Informe Cadbury de 1992 se centra, precisamente, en el funcionamiento del Directorio de las sociedades abiertas británicas. Sin embargo, en los últimos años la tendencia a nivel del Derecho Comparado es la de incluir disposiciones imperativas de carácter legal para mejorar el funcionamiento de este órgano en las sociedades anónimas abiertas.

Sobre esta problemática, central en el gobierno corporativo, nuestra legislación está lamentablemente desfasada. La LGS no incluyó disposiciones especiales para el Directorio de la sociedad anónima abierta y las únicas disposiciones especiales contenidas en la LMV o dictadas posteriormente tenían que ver con temas vinculados al conflicto de intereses o la responsabilidad del Directorio. $Y$ si bien esos son aspectos útiles y relevantes, nuestra legislación no ha recogido avances que son fundamentales en la regulación del Directorio a nivel del Derecho Comparado de los últimos años.

(24) Por supuesto, además de estas disposiciones de carácter legal y reglamentario, la sociedad anónima abierta puede estar sujeta a códigos de gobierno corporativo de cumplimiento voluntario u obligatorio, y a los estándares de listado de las Bolsas de Valores en las que cotizan sus acciones, cuerpos normativos que pueden regular tanto aspectos propios del mercado de valores en si (por ejemplo, deberes de información generales), como aspectos propiamente societarios (por ejemplo, composición del Directorio).

(25) Ello es natural, habida cuenta del rol central de este órgano en el gobierno de la sociedad anónima. Como lo expresa Hopt, "el núcleo central de la sociedad anónima es el board (...) Los miembros del Consejo de administración gestionan la sociedad y los accionistas, que no pueden acometer por sí mismos esta función, delegan en ellos esta tarea. En este punto surge la cuestión principal del corporate governance, que no es otra que cómo pueden los accionistas asegurar que el board gestione la sociedad correcta y lealmente". Klaus J. Hopt, Derecho de Sociedades y del Mercado de Valores (Madrid: Marcial Pons, 2010), 41. 


\section{José Antonio Payet Puccio}

El primero tiene que ver con las disposiciones imperativas dictadas para reforzar la efectividad del Directorio en materia de supervisión de las operaciones sociales y control de la calidad y confiabilidad de la información financiera. Esta es una tendencia a nivel internacional que se origina en la reacción legislativa en los Estados Unidos ante el colapso de Enron. En los Estados Unidos, se consideró que la quiebra de Enron había sido causada en gran parte por fallas en el funcionamiento del Directorio y de la Auditoría Externa de la sociedad (26). Como resultado de ello, el 12 de Julio de 2002 se dictó la Ley Sarbanes-Oxley (SOX), la que estableció a nivel federal la obligación de las sociedades listadas de tener un Comité de Auditoría conformado exclusivamente por directores independientes ${ }^{(27)}$. La ley señala que para ser independiente, un director no debe estar vinculado al emisor ni debe recibir ningún tipo de compensación del emisor o sus entidades vinculadas, salvo por la que le corresponda específicamente en su calidad de director. Asimismo, estableció que las funciones del Comité de Auditoria incluyen la aprobación de cualquier servicio (sea o no de auditoría) a ser prestado por Auditores Externos del emisor y sus compañías vinculadas. La Ley SOX establece también un marco regulatorio para las firmas de auditoría, medidas destinadas a garantizar su independencia frente a la compañía auditada (como por ejemplo prohibiciones de brindarle ciertos tipos de servicios), y obliga a ciertos funcionarios del emisor a hacerse responsables de la fiabilidad de la información financiera de la compañía.

La Ley SOX generó una tendencia hacia establecer para las sociedades anónimas abiertas la obligación de contar con un Comité de Auditoría conformado totalmente o mayoritariamente por directores independientes, la misma que ha sido seguida en muchas jurisdicciones. En este sentido, por ejemplo, la Ley de Sociedades de Capital de España señala que las sociedades cotizadas deberán contar con una
Comisión de Auditoría, la cual deberá estar compuesta "exclusivamente por consejeros no ejecutivos nombrados por el consejo de administración, dos de los cuales, al menos, deberán ser consejeros independientes y uno de ellos será designado teniendo en cuenta sus conocimientos y experiencia en materia de contabilidad, auditoría o en ambas". Asimismo, la Ley del Mercado de Valores de México establece que las sociedades anónimas bursátiles deberán tener un comité de prácticas societarias y uno de auditoria (o uno solo que agrupe ambas funciones), compuestos exclusivamente por directores independientes (salvo en el caso de sociedades en las cuales un accionista tenga directa o indirectamente más del $50 \%$ de las acciones, en las cuales el comité puede conformarse con mayoría de miembros independientes). Finalmente, la Ley de Sociedades Anónimas de Chile señala que las sociedades anónimas abiertas que tengan un patrimonio bursátil de al menos 1,500,000 unidades de fomento ${ }^{(28)}$ y al menos $12.5 \%$ de su capital en manos de accionistas que posean individualmente menos del $10 \%$ del capital social, deberán tener un comité del Directorio, cuyas funciones corresponden con las tradicionales de los Comités de Auditoría, el cual deberá estar conformado por tres miembros, de los cuales al menos dos deberán ser independientes.

En adición a ello, algunas legislaciones han establecido en forma más detallada y precisa los deberes del Directorio, incluyendo el

(26) En un informe resultado de las investigaciones del Senado de los Estados Unidos sobre la materia, se concluyó que "el Directorio de Enron dejó de proteger a los accionistas de Enron y contribuyó al colapso de la sétima compañía pública más grande de los Estados Unidos, al permitir a Enron involucrarse en prácticas de auditoría de alto riesgo, transacciones con conflicto de intereses inapropiadas, numerosas operaciones no contabilizadas en los libros de la sociedad, y remuneración de ejecutivos excesiva (...)". The Role of the Board of Directors in Enron's Collapse, Report Prepared by the Permanent Subcommittee in Investigations of the Committee on Governmental Affairs, United States Senate, Julio 8, 2002, 3.

(27) Se permite que el Directorio, de estar compuesto exclusivamente por directores independientes, asuma dicha función. Para una visión crítica de la Ley SOX, véase Roberta Romano, "The Sabanes-Oxley Act and the Making of Quack Corporate Governance," The Yale Law Journal 114: 1521 y siguientes.

(28) Al 28 de mayo de 2017, equivalente a aproximadamente 60 millones de dólares de los Estados Unidos de América. 
La Sociedad Anónima Abierta: algunas ideas para la reforma de su tratamiento legislativo The Open Stock Corporation: some ideas for the reform of its legislative treatment

ampliar la relación de facultades indelegables. Por ejemplo, las modificaciones hechas en 2014 a la Ley de Sociedades de Capital de España han incluido dentro de las facultades indelegables del Consejo de Administración para todas las sociedades de capital, no solo las sociedades cotizadas, la supervisión de las comisiones creadas por el propio Consejo (incluyendo la de auditoria, obligatoria para las sociedades cotizadas), la determinación de las políticas y estrategias generales de la sociedad, la autorización o dispensa de las obligaciones derivadas del deber de lealtad (por ejemplo, autorización de una operación entre el consejero y la sociedad), la propia organización y funcionamiento del Consejo, el nombramiento y destitución de los consejeros delegados (equivalentes a los gerentes), las decisiones relativas a remuneración de consejeros, la convocatoria a Junta General de Accionistas y la propuesta de acuerdos, y la política relativa a autocartera ${ }^{(29)}$. Asimismo, en la Ley del Mercado de Valores de México se establece un detallado listado de competencias del Consejo, incluyendo las de establecer las estrategias generales de la sociedad y sus subsidiarias y vigilar su gestión y conducción, el nombramiento y la destitución del director general de la sociedad, los lineamientos en materia de control interno, las políticas contables de la sociedad, la selección y contratación de los auditores externos, la memoria y los estados financieros anuales a presentar a la Junta General de Accionistas, etcétera.

Algunas legislaciones han incorporado también a nivel de derecho positivo con carácter imperativo otras recomendaciones de los Códigos de Gobierno Corporativo, o de los requisitos de listado de las Bolsas de Valores. El requisito más extendido es el de incorporar directores independientes en las sociedades anónimas abiertas, requisito que en algunos casos deriva de la necesidad de contar con dichos directores para poder conformar el Comité de Auditoría y en otros se plasma de manera adicional. Así, por ejemplo, en la Ley de Mercado de Valores de México se establece que el $25 \%$ de los integrantes del Directorio de una sociedad anónima bursátil deben ser independientes. Y si bien la institución misma del director independiente ha sido criticada (en particular, por alegarse su falta de efectividad en prevenir la crisis financiera del 2008), las recomendaciones de solución van más por el lado de mejorar la selección y la actuación de los directores independientes, antes que por descartar su utilidad ${ }^{(30)}$.

Considero que en este marco, es necesario incorporar en la LGS disposiciones especiales destinadas a mejorar el funcionamiento del Directorio en las sociedades anónimas abiertas, en armonía con las mejores prácticas internacionales en la materia. En este contexto, creo que debe establecerse que en la sociedad anónima abierta el Directorio debe contar necesariamente con al menos un determinado porcentaje de directores independientes y con un Comité de Auditoría conformado mayoritariamente por directores independientes. Debe definirse a nivel legislativo en que consiste la condición de director independiente, identificando las circunstancias que determinen que el director no pueda ser considerado como tal.

Asimismo, considero que debe igualmente establecerse un listado de las principales atribuciones y responsabilidades del Directorio, señalando dentro de ellas las que tienen carácter indelegable. Por ejemplo, debe establecerse que es de responsabilidad del Directorio el fijar la estrategia general de negocios de la sociedad y supervisar y controlar su gestión, designar y remover al principal ejecutivo, designar o proponer la designación del auditor externo, designar a los comités delegados, fijar las políticas contables y supervisar la fiabilidad de la información financiera de la sociedad, establecer y supervisar las políticas y los

(29) Véase Javier García de Enterría, dir., La Reforma de la Ley de Sociedades de Capital en Materia de Gobierno Corporativo (Pamplona: Aranzadi, 2015), 84 y siguientes.

(30) Véase, por ejemplo, María Gutiérrez Urtiaga y María Isabel Sáez Lacave, "El Mito de los Consejeros Independientes," InDret 2 (2012): 1-44. Disponible en http://Indret.com. 


\section{José Antonio Payet Puccio}

sistemas de control de riesgos, etcétera. Esta es una modificación que es necesaria para todas las sociedades anónimas, pero en especial para las sociedades anónimas abiertas.

De otro lado, considero que en la sociedad anónima abierta el número mínimo de integrantes del Directorio debería posiblemente ser mayor que el de tres que prevé el artículo 155. Un Directorio de tres integrantes implica una participación de un tercio en el capital para poder designar un director, lo cual puede ser excesivo para una sociedad abierta. Además de ello un número de tres integrantes parece insuficiente para el adecuado cumplimiento de las tareas y responsabilidades que corresponden al Directorio en una sociedad anónima abierta. Es cierto que la exigencia de directores independientes puede contrapesar este requisito, pero tal vez un número mínimo de cinco sea más adecuado a una sociedad bursátil.

Por otra parte, creo que es muy importante que se regule en forma más precisa, a nivel de la sociedad anónima abierta, el proceso de elección del Directorio, con la finalidad de garantizar que dicho órgano se conforme respondiendo efectivamente a la voluntad de todos los accionistas de la sociedad, formada en la Junta General de Accionistas. Probablemente la decisión más importante que adopta la Junta General de Accionistas de una sociedad anónima abierta es la referida a la elección del Directorio, por lo que es fundamental que el marco legal garantice la transparencia y corrección del proceso de toma de decisión correspondiente.

Considero que en materia de la sociedad anónima abierta debe establecerse la aplicación obligatoria del sistema de votación acumulativa previsto en el artículo 164 de la LGS, con la única excepción de cuando el Directorio es elegido con el voto unánime de todos los accionistas representados en la Junta General. Creo que en la sociedad anónima abierta no debe ser de aplicación la disposición contenida en el penúltimo párrafo del referido artículo en cuanto a que "el estatuto puede establecer un sistema distinto, siempre que la representación de la minoría no resulte inferior".

Creo que además que el proceso de elección del Directorio en aplicación del sistema de voto acumulativo previsto en el artículo 164 de la LGS debe ser normado con mayor detalle para las sociedades anónimas abiertas. En particular, considero que es necesario señalar expresamente el procedimiento para que, además de los candidatos que proponga la misma administración, los accionistas puedan formular propuestas de candidatos (por ejemplo, antes de la Junta) y que se debe regular el procedimiento de voto en la junta, en el cual debería votarse individualmente por cada candidato.

\subsection{Responsabilidad de los Directores} Considero acertadas las disposiciones establecidas en el artículo 4 de la Ley 29720 , que redujeron para la sociedad anónima cotizada el porcentaje del capital necesario para que proceda la interposición de la pretensión social de responsabilidad por accionistas individuales, y establecieron el derecho a exigir al Directorio la entrega de la documentación relevante. Es cierto que el porcentaje del $10 \%$ puede considerarse elevado si se compara con los porcentajes que prevalecen en otras jurisdicciones como México (5\%), España (3\%), pero la esencia de la disposición es correcta y debe ser mantenida.

Sin embargo, de la mano de ello, considero que es indispensable recoger a nivel de nuestro Derecho disposiciones destinadas a proteger el juicio de negocios de los administradores, inspiradas en la business judgement rule del Derecho de Sociedades norteamericano. Como lo expuso magistralmente Cándido Paz-Ares hace ya bastantes años, "el régimen de responsabilidad de los administradores ha de configurarse de modo que sea tan severo con las infracciones del deber de lealtad como indulgente con las infracciones del deber de diligencia" (Paz-Ares 2003, 5).

La prédica de Cándido ha encontrado eco. En este sentido, por ejemplo, en la Ley de Sociedades de Capital de España se ha incluido el artículo 226, titulado Protección 
La Sociedad Anónima Abierta: algunas ideas para la reforma de su tratamiento legislativo The Open Stock Corporation: some ideas for the reform of its legislative treatment

de la discrecionalidad empresarial, aplicable a todas las sociedades de capital, el que establece lo siguiente: "En el ámbito de las decisiones estratégicas y de negocio, sujetas a la discrecionalidad empresarial, el estándar de diligencia de un ordenado empresario se entenderá cumplido cuando el administrador haya actuado de buena fe, sin interés personal en el asunto objeto de decisión, con información suficiente y con arreglo a un procedimiento de decisión adecuado (...)". Un estándar similar ha sido establecido para los integrantes de consejo de administración de las sociedades anónimas bursátiles en la Ley del Mercado de Valores de México, la cual señala que "los miembros del consejo de administración no incurrirán (...) en responsabilidad por los daños y perjuicios que ocasionen a la sociedad (...) derivados de los actos que ejecuten o las decisiones que adopten, cuando actuando de buena fe (...) hayan seleccionado la iniciativa más adecuada, a su leal saber y entender (...) con base en la información disponible al momento de la decisión".

De esta manera, se busca que los integrantes del Directorio sean responsables frente a la sociedad o los accionistas por daños causados por decisiones empresariales, solo en caso en que hayan obrado de mala fe, en situación de conflicto, o sin seguir un proceso adecuado de toma de decisiones. Así, de la mano de disposiciones procedimentales que eliminen dificultades a la pretensión social de responsabilidad, debe crearse un ámbito de protección a la discrecionalidad empresarial, que permitan a los administradores tomar de buena fe, las decisiones inherentes a la actividad empresarial, sin temor de verse perseguidos judicialmente en caso que las cosas no resulten como se esperaba razonablemente al momento de tomar la decisión.

\subsection{Transacciones con Partes Relacionadas}

Las transacciones que celebre una sociedad anónima abierta con entidades vinculadas a su accionista de control o a sus directores o gerentes -las denominadas transacciones entre partes relacionadas- deben ser reguladas a nivel de la Ley General de Sociedades. En este sentido, debe incorporarse en la LGS la regulación pertinente, actualmente contenida en el inciso c del artículo 51 de la LMV, corrigiendo los defectos que actualmente presenta dicha disposición. Al respecto me remito al artículo publicado hace algún tiempo sobre esta problemática(31).

\subsection{Funcionamiento de la Junta General} No creo que sea necesario realizar modificaciones mayores a las normas especiales en materia de Junta General de Accionistas de la sociedad anónima abierta contenidas en la LGS, el mismo que considero que es generalmente adecuado. Sin embargo, sí considero que deben perfeccionarse algunas disposiciones puntuales.

La primera de ellas está referida a la prohibición contenida en el artículo 257 de la LGS, en el sentido que "el estatuto no puede exigir quórum ni mayoría más altas" a las previstas en dicha disposición. Esta disposición imperativa, que viene del Decreto Legislativo 672, limitando la capacidad de los socios de ordenar sus propios asuntos estableciendo una mayoría más alta que la legal, no parece tener mayor sentido. Podría eventualmente pensarse que en una sociedad con una gran dispersión del accionariado, si el estatuto establece quórum y mayorías más altas, la sociedad podría caer en parálisis. Sin embargo, hay dos factores que tener presentes. El primero es que estas mayorías más altas serían establecidas en ejercicio de las facultades de autodeterminación de los socios, de manera que no cabe suponer, a priori, que los propios socios establecerán voluntariamente una regla de quórum y mayorías que conduciría a la parálisis de la Junta General de Accionistas. $Y$ el segundo factor es que la realidad de las sociedades anónimas abiertas peruanas es de la presencia de bloques accionariales importantes -en la mayoría de los casos mayoritarios- que hacen altamente improbable que tal parálisis se produzca en la práctica. Más bien, parece que la LGS ha eliminado la posibilidad de que, estatutariamente, se consagre reglas de protección de minorías

(31) Véase José Antonio Payet, “Transacciones entre Partes Relacionadas," IUS ET VERITAS 48 (julio): $152-78$. 


\section{José Antonio Payet Puccio}

(por la vía de la mayoría calificada), lo cual es un efecto indeseado y contradictorio a la finalidad de la norma(32).

El segundo cambio puntual que considero recomendable tiene que ver con los plazos de convocatoria y registro de acciones para las Juntas Generales de Accionistas. De acuerdo con el artículo 258 de la LGS, el aviso de convocatoria a Junta General de Accionistas de una sociedad anónima abierta debe publicarse con 25 días de anticipación; y las acciones con derecho a concurrir a la Junta deben estar inscritas con diez días de anticipación. Creo que ambos plazos son excesivos, teniendo en cuenta la fluidez de las comunicaciones contemporáneas. El excesivo plazo para la convocatoria a la Junta puede retrasar la toma de decisiones empresariales necesarias. Asimismo, el plazo de diez días para que el adquirente de acciones pueda participar en una Junta (que se sumaría además a los 3 días hábiles de la liquidación bursátil), puede afectar el legítimo derecho de un accionista a participar en la Junta General. Creo, en ese sentido, que ambos plazos deben reducirse significativamente.
Por último, como se ha señalado anteriormente, considero que es necesario que se establezca expresamente, dentro de las decisiones de competencia de la Junta General de Accionistas, la de decidir la inscripción de las acciones de la sociedad en Bolsa de Valores y la exclusión de dichas acciones del referido mercado. Ello es sin perjuicio del derecho de accionistas que representen el $25 \%$ del capital de exigir el listado de sus acciones.

\subsection{Derechos de Minoría Calificada}

Como se sabe, la legislación societaria confiere una serie de derechos a las minorías, los mismos que en muchos casos requieren un porcentaje mínimo del capital para poder ser ejercidos ${ }^{(33)}$. Teniendo en cuenta el grado de dispersión accionarial que muchas veces caracteriza a la sociedad anónima abierta, con frecuencia los límites cuantitativos exigidos para poder ejercer estos derechos de minoría

\begin{tabular}{|l|l|l|l|}
\hline \multicolumn{1}{|c|}{ Derecho } & \multicolumn{1}{|c|}{ SA } & \multicolumn{1}{c|}{ SAA } & \multicolumn{1}{c|}{ Disposición Legal } \\
\hline Información fuera de Junta & $5 \%$ del capital pagado & $5 \%$ del capital pagado & Artículo 52 LGS \\
\hline $\begin{array}{l}\text { Convocatoria a Junta General de } \\
\text { Accionistas }\end{array}$ & $\begin{array}{l}20 \% \text { del capital suscrito con derecho } \\
\text { a voto }\end{array}$ & $\begin{array}{l}5 \% \text { del capital suscrito con derecho } \\
\text { a voto }\end{array}$ & Artículos 117 y 255 LGS \\
\hline Aplazamiento de la Junta General & $\begin{array}{l}25 \% \text { del capital suscrito con derecho } \\
\text { a voto }\end{array}$ & $\begin{array}{l}25 \% \text { del capital suscrito con derecho } \\
\text { a voto }\end{array}$ & Artículo 131 LGS \\
\hline $\begin{array}{l}\text { Presencia de Notario en Junta } \\
\text { General }\end{array}$ & $\begin{array}{l}20 \% \text { del capital suscrito con derecho } \\
\text { a voto }\end{array}$ & $\begin{array}{l}20 \% \text { del capital suscrito con derecho } \\
\text { a voto }\end{array}$ & Artículo 138 LGS \\
\hline $\begin{array}{l}\text { Suspensión de acuerdo en caso de } \\
\text { impugnación }\end{array}$ & $20 \%$ del capital suscrito & $20 \%$ del capital suscrito & Artículo 145 LGS \\
\hline $\begin{array}{l}\text { Ejercicio de pretensión social de } \\
\text { responsabilidad }\end{array}$ & $10 \%$ del capital suscrito & $33.33 \%$ del capital suscrito & $\begin{array}{l}\text { Artículo } 181 \text { LGS, artículo } \\
\text { 4 Ley 29720 }\end{array}$ \\
\hline Auditorias Especiales & $\begin{array}{l}10 \% \text { del capital suscrito con derecho } \\
\text { a voto }\end{array}$ & $\begin{array}{l}10 \% \text { del capital suscrito con derecho } \\
\text { a voto }\end{array}$ & Artículo 227 LGS \\
\hline Dividendo Mínimo & $\begin{array}{l}20 \% \text { del capital suscrito con derecho capital suscrito con derecho } \\
\text { a voto }\end{array}$ & Artículo 231 LGS \\
\hline
\end{tabular}

(32) Podría pensarse también que esta disposición es una forma de garantizar el libre funcionamiento del mercado de control societario para las sociedades anónimas abiertas, en forma análoga a las disposiciones sobre neutralización que existen en el Artículo 11 de la Directiva No. 2004//25/CE del Parlamento Europeo y del Consejo de 21 de abril de 2004 relativa a las ofertas públicas de adquisición. Sin embargo, ese tipo de disposiciones están vinculadas a supuestos muy específicos de cambio de control.

(33) Véase Javier Juste Mencia, Los Derechos de Minoría en la Sociedad Anónima (Pamplona: Aranzadi, 1995). 
La Sociedad Anónima Abierta: algunas ideas para la reforma de su tratamiento legislativo The Open Stock Corporation: some ideas for the reform of its legislative treatment

calificada son menores para estas sociedades que para las sociedades anónimas ordinarias. En el caso de la LGS, las normas sobre sociedad anónima abierta reducen los límites solo para algunos derechos de minoría calificada, pero no lo hacen para otros derechos.

En el cuadro anterior se presenta la comparación de los porcentajes accionarios requeridos para los distintos derechos de minoría calificada contemplados en la LGS.

Como se puede ver de este cuadro, salvo por los casos de la convocatoria a Junta General de Accionistas y del ejercicio por accionistas de la pretensión social de responsabilidad, la LGS ha mantenido los mismos porcentajes en la sociedad anónima ordinaria y en la sociedad anónima abierta para el ejercicio de los derechos de minoría calificada. En mi opinión, resulta necesario revisar estos porcentajes, pues los establecidos para la sociedad anónima ordinaria pueden resultar excesivos para una sociedad anónima abierta.

Por otro lado, creo que, al menos en el caso de la sociedad anónima abierta, se debe incluir entre los derechos de minoría calificada también los de incluir puntos en la agenda de una Junta General de Accionistas ya convocada (y no solo de pedir la convocatoria a una Junta) y de proponer candidatos al Directorio.

\subsection{Finanzas Corporativas}

Teniendo en cuenta su naturaleza de sociedad bursátil, considero que la sociedad anónima abierta debe ser liberada de algunas restricciones que afectan las finanzas corporativas de la sociedad anónima ordinaria, actualmente establecidas en la LGS con carácter general.

Así, en primer lugar, considero que no debe ser de aplicación a una sociedad anónima abierta el dividendo obligatorio que establece el artículo 321 de la LGS. A mi criterio, una norma que otorgue a una minoría accionaria la potestad de imponer la distribución de un dividendo es algo que no debería existir para ninguna sociedad, pues ello implica poner de cabeza el principio de las mayorías y permitir a la minoría imponer decisiones de asignación de recursos sociales. Pero esto, si se quiere, es aún más absurdo en una sociedad cotizada. La sociedad anónima abierta debe contar con una política de dividendos aprobada por su Junta General de Accionistas y comunicada al mercado, como actualmente lo establece la
LMV. Sobre la base de esa política, como uno más de los datos relevantes para una decisión de inversión, los inversionistas decidirán si compran o no las acciones de dicha sociedad. Por ello, en ningún caso debería aceptarse que una minoría accionaria imponga la distribución de utilidades.

Por otro lado, considero que las disposiciones en materia de autocartera deben flexibilizarse para las sociedades anónimas abiertas. Estas sociedades reportan sus estados financieros de manera trimestral y además están obligadas a informar como hecho de importancia las operaciones que realicen con acciones de propia emisión, de manera que su cifra de capital social registral o escriturario en realidad aporta muy poca información sobre su situación financiera real. En tal sentido, considero que, en tanto se establezca que las política de autocartera y los parámetros para las operaciones deben ser aprobadas por la Junta General de Accionistas (aprobación que, por ejemplo, debería ser ratificada anualmente en la Junta Obligatoria Anual), la autocartera se refleje apropiadamente en los Estados Financieros y las operaciones correspondientes se reporten como hecho relevante, deberían flexibilizarse para las sociedades anónimas abiertas los límites que son aplicables actualmente a estas operaciones en el caso de todas las sociedades anónimas de acuerdo con el artículo 104 de la LGS.

Finalmente, creo que deben eliminarse para las sociedades abiertas las limitaciones al apalancamiento por la vía de emisión de obligaciones que establece el artículo 305 de la LGS. Al igual que el dividendo obligatorio del artículo 231, una norma imperativa que, sin siquiera atender a la naturaleza de la actividad o tipo de negocio de la sociedad, señale con carácter general que las obligaciones en circulación no pueden superar el patrimonio neto de la sociedad salvo que cuenten con 


\section{José Antonio Payet Puccio}

garantía, es una norma que no tiene mayor sentido para ninguna sociedad anónima. Menos sentido aun lo tiene para una sociedad que opera en el mercado de valores, como una sociedad anónima abierta.

\subsection{Deslistado y Squeeze-Out}

He señalado anteriormente que para promover el desarrollo del mercado de capitales y el financiamiento de las empresas por la vía de la emisión de acciones, es necesario no solo reducir las barreras de entrada el mercado de oferta pública y mejorar los estándares de transparencia y gobierno corporativo de los emisores, sino también permitir a los emisores la salida del mercado público de valores cuando ello sea necesario. En materia de sociedades anónimas abiertas ello implica a mi criterio dos aspectos principales.

El primero tiene que ver con la facultad de proceder al deslistado de las acciones y su exclusión del mercado bursátil. Esta materia no ofrece mayor dificultad. La LMV ya establece que el emisor puede disponer el deslistado de un valor, en cuyo caso queda obligado a realizar una oferta pública de compra (OPC), la misma que implica ofrecer al público un precio justo de mercado establecido por una entidad valorizadora independiente. El deslistado determinará que la sociedad anónima abierta pierda la calidad de tal, de manera que la OPC cumple un rol similar al que cumpliría el derecho de separación ante esta modificación estructural en la sociedad.

El segundo es el incorporar a nuestra legislación la institución del denominado sqeeze-out. En efecto, considero que es necesario recoger a nivel de nuestro derecho, la institución de la compra y venta obligatoria que consagran muchas legislaciones societarias, para el supuesto en el que como resultado de una oferta pública, un accionista acumule un porcentaje mayoritario muy elevado de la compañía. Conforme a esta institución, en caso que una persona acumule un porcentaje accionario determinado (por ejemplo, $90 \%$ o más) tiene derecho a exigir que los restantes accionistas le transfieran sus acciones, a cambio de un precio que ha de ser un precio justo sujeto a verificación por la autoridad competente. Ello permite que la sociedad en cuestión pase a ser una compañía plenamente privada y pueda ser gestionada por el controlador sin necesidad de atender a las disposiciones de protección de accionistas minoritarios ${ }^{(34)}$.

Por ejemplo, la Directiva de la Unión Europea en materia de Ofertas Públicas de Adquisición señala lo siguiente:

"Los Estados miembros velarán por que un oferente pueda exigir a los restantes titulares de valores que le vendan dichos valores a un precio justo. Los Estados miembros establecerán este derecho en una de las situaciones siguientes: a) cuando el oferente posea valores que representen al menos el $90 \%$ del capital que confiere derechos de voto y el $90 \%$ de los derechos de voto de la sociedad afectada, o b) cuando haya adquirido o se haya comprometido en firme a adquirir, en virtud de la aceptación de su oferta, valores que representen al menos el $90 \%$ del capital social de la sociedad afectada que confiera derechos de voto y el $90 \%$ de los derechos de voto incluidos en la oferta. En el caso contemplado en la letra a), los Estados miembros podrán fijar un umbral más elevado que, no obstante, no podrá ser superior al $95 \%$ del capital que confiera derechos de voto y al $95 \%$ de los derechos de voto"(35).

La Directiva consagra también un derecho espejo de los accionistas minoritarios para exigir al controlador la compra de sus acciones.

(34) Para una revisión de la justificación económica de la institución y de su sustento jurídico, véase Cándido Paz-Ares, "Aproximación al Estudio de los Squeeze-Outs en Derecho Español," Actualidad Jurídica Uría Menéndez 2 (2002). Véase también Juan Antonio Eguez, "Squeeze-Outs en Derecho Peruano," Advocatus 8 (2003): 189 y siguientes.

(35) Directiva No. 2004//25/CE del Parlamento Europeo y del Consejo de 21 de abril de 2004 relativa a las ofertas públicas de adquisición, artículo 15 . 
La Sociedad Anónima Abierta: algunas ideas para la reforma de su tratamiento legislativo The Open Stock Corporation: some ideas for the reform of its legislative treatment

La Directiva ha sido implementada a nivel del Derecho Interno de los países miembros lo largo de la Unión Europea. Un derecho similar de compra y venta forzosa ha sido establecido en Chile, en el marco de la reforma de la Ley de Sociedades Anónimas realizada por Ley 20328 , en octubre de 2009, para los casos en los que se alcance el $95 \%$ del capital.

\subsection{Entidad Competente}

Un último tema, pero claramente no el menos importante, es la cuestión del enforcement, o de los mecanismos para poder exigir el cumplimiento de las normas. Si no existen mecanismos efectivos para exigir el cumplimiento de las disposiciones legales, esas se vuelven, literalmente, letra muestra, y no valen ni el papel en el que están impresas.

En materia societaria, el enforcementestá referido básicamente a derechos de carácter privado. Me refiero, por ejemplo, al ejercicio de los derechos de minoría calificada, a la impugnación de acuerdos societarios, a la interposición de acciones de responsabilidad contra administradores, etcétera. Es de toda conocida la multiplicidad de problemas que aquejan al Poder Judicial, el cual, lamentablemente, no es hoy una alternativa eficaz para hacer efectivos los derechos que consagra la legislación societaria. Lentitud, falta de tecnicismo, análisis superficial, formalismo, falta de predictibilidad, y, en algunos casos, venalidad, son todos defectos fatales para un órgano de resolución de conflictos, que hacen que, por la vía judicial, los derechos societarios sean, en la mayoría de los casos, inejecutables.

La vía del arbitraje es una opción interesante y existen antecedentes a nivel del Derecho Comparado de imposición de un arbitraje obligatorio, al menos para una de las partes ${ }^{(36)}$. Sin embargo, en general el arbitraje requiere un sometimiento voluntario, de manera que no considero que sea sustentable imponerlo como mecanismo obligatorio a nivel legal. Sí pienso que sería muy interesante y ameritaría un estudio más profundo el contemplar que la Bolsa de Valores de Lima prevea un mecanismo arbitral para la solución de conflictos societarios de sus emisores listados. Ello podría hacerse incluyendo como parte de los requisitos de listado o como parte de los recomendaciones o estándares en materia de gobierno corporativo de la Bolsa, el que los emisores listados acepten incluir una cláusula arbitral en sus estatutos. Otra alternativa, posiblemente complementaria, es otorgar mayores facultades a la Superintendencia del Mercado de Valores, con respecto a las sociedades anónimas abiertas. Se trata de un aspecto vital para la mejora del marco institucional de la sociedad cotizada en el Perú, que requiere un análisis más profundo del que es objeto de este trabajo, pero que resulta indispensable y urgente.

\section{Referencias bibliográficas}

Elias Laroza, Enrique. 1998. Ley General de Sociedades comentada. Trujillo: Editorial Normas Legales.

European Commission. 2011. Report of the Reflection Group on the Future of EU Company Law. Bruselas, 5 de abril. https:// doi.org/10.2139/ssrn.1851654

Fernández-Pérez, Nuria. 2011. Sociedades Anónimas Cotizadas. En Comentario de la Ley de Sociedades de Capital, coords. Ángel Rojo y Emilio Beltrán, 3265-72. Tom. 2. Vol. 2. Pamplona: Civitas.

Ferrero Diez-Canseco, Alfredo. 1998. Las formas especiales de sociedad anónima en la nueva Ley General de Sociedades. Themis 37, 17-33.

Galgano, Francesco. 1981. Historia del Derecho Mercantil. Barcelona: Editorial Laia.

Hopt, Klaus J. 2011. Comparative Corproate Governance: The State of the Art and

(36) Es el caso del artículo 4, inciso 10, de la Ley de Sociedades Anónimas de Chile. 


\section{José Antonio Payet Puccio}

International Regulation. ECGI Working Paper Series in Law No. 170. Disponible en: http://ssrn.com/abstract=1713750. https://doi. org/10.5131/ajcl.2010.0025

Normand Sparks, Enrique. 2009. Ley General de Sociedades. Lima: Edinver Editores.

Paz-Ares, Cándido.2003. La Responsabilidad de los Administradores como instrumento de Gobierno Corporativo. InDret 4 (2003): 1-61. Disponible en: http://indret.com.
Payet, José Antonio. 2003. Empresa, Gobierno Corporativo y Derecho de Sociedades: reflexiones sobre la protección de las minorías. Themis 46: 77-103.

2009. Transacciones entre partes relacionadas. IUS ET VERITAS 48 (julio): 152-78.

Tapia Ermina, Alberto Javier. 2010. Las Sociedades Cotizadas: Noción y Estatuto Juridico. Madrid, Documentos de Trabajo del Departamento de Derecho Mercantil, Universidad de Complutense. Disponible en: http://ucm.es/info/mercantil. 